\title{
Open-ocean foraging ecology of southern bluefin tuna Thunnus maccoyii based on stomach contents
}

\author{
Tomoyuki Itoh* ${ }^{*}$ Osamu Sakai
}

National Research Institute of Far Seas Fisheries, Fisheries Research Agency, 5-7-1 Orido, Shimizu-ku, Shizuoka-shi, Shizuoka-ken, 424-8633, Japan

\begin{abstract}
We investigated the foraging ecology of southern bluefin tuna Thunnus maccoyii in open-ocean habitats of temperate waters in the southern hemisphere by analyzing their stomach contents. Samples were collected from longline vessels over $15 \mathrm{yr}(\mathrm{n}=4649)$. Of the prey, $51 \%$ by weight were cephalopods and $46 \%$ were teleosts. These values differ from those in the literature for other top predators in the open oceans, for which teleosts compose the largest portion of prey. The dominance of cephalopods also differs from the pattern for juveniles in previous studies in their coastal habitat, where most of the prey are teleosts. Thus, a distinct shift of prey occurs along with the habitat shift due to ontogenetic development. By weight, important prey were ommastrephid $(18 \%)$, lycoteuthid $(12 \%)$, and argonautid $(1 \%)$ cephalopods and nomeid (8\%, mainly Cubiceps caeruleus), paralepidid $(7 \%)$, bramid $(6 \%)$, and alepisaurid $(6 \%)$ teleosts. The prey composition was relatively consistent among tuna sizes, sea surface temperatures, and years; changes in prey composition were due largely to differences in the cephalopod prey. Cephalopods belonging to the families Lycoteuthidae and Argonautidae contributed to the prey only off the southern coast of Africa and near Tasmania, respectively. Lycoteuthids occurred at lower sea surface temperatures than ommastrephids off the southern coast of Africa. Small ommastrephids were dominant in smaller tuna in the southeastern Indian Ocean. Our data provide basic information that will improve our understanding of the oceanic food webs in southern temperate waters.
\end{abstract}

KEY WORDS: Food web $\cdot$ Diet $\cdot$ Cephalopod $\cdot$ Multidimensional scaling $\cdot$ Ommastrephidae

\section{INTRODUCTION}

Understanding of the predator-prey relationships in the oceanic ecosystem is important both for understanding the ecology of marine animals and for fisheries management in an ecosystem-based approach (Garcia \& Cochrane 2005). The open ocean is a habitat for many highly migratory species, including tuna Thunnus spp., and the interactions between fisheries and the open-ocean ecosystem have been analyzed using ecosystem models (Cox et al. 2002, Griffiths et al. 2010). The success of such models depends on the accumulation of knowledge based on actual observations of predator-prey relationships. Top predators can serve as a biological sampler for populations of

${ }^{*}$ Corresponding author: itou@fra.affrc.go.jp mid-trophic-level animals because their stomach contents provide useful insights into food webs (Young et al. 2015). Many studies of the foraging ecology of tuna species have been performed in open oceans of the North Atlantic, eastern North Pacific, eastern South Pacific, central western Pacific, and western Indian oceans (e.g. Moteki et al. 2001, Bertrand et al. 2002, Potier et al. 2007, Butler et al. 2010, Young et al. 2010, Logan et al. 2011, Olson et al. 2014). However, there have been few food-web studies in the circumpolar southern temperate waters in the southern hemisphere at latitudes between $30^{\circ}$ and $50^{\circ} \mathrm{S}$ that extend across 3 oceans (but see Young et al. 1997).

Southern bluefin tuna (SBT) Thunnus maccoyii is a representative species of the top predators in this

() The authors 2016. Open Access under Creative Commons by Attribution Licence. Use, distribution and reproduction are unrestricted. Authors and original publication must be credited. 
area. SBT are distributed throughout the circumpolar area between $30^{\circ}$ and $50^{\circ} \mathrm{S}$ in the Atlantic, Indian, and Pacific oceans (Caton 1991). SBT are a single stock, and their only known spawning area is in the tropical eastern Indian Ocean, southeast of Java, Indonesia (Shingu 1978, Grewe et al. 1997, Farley et al. 2007). Juvenile SBT grow in the coastal waters along the western and southern coasts of Australia, and migrate seasonally between the southern coast of Australia and the central southern Indian Ocean (Hobday et al. 2016). By age 5, most SBT are found in open-ocean waters, where they mature between ages 8 and 12. Adult SBT exhibit large-scale migrations for spawning and, in their seasonal movements, for foraging (Gunn \& Block 2001, Patterson et al. 2008). They spend most of their lives in the open ocean, where they reach more than $200 \mathrm{~cm}$ fork length $\left(\mathrm{FL}_{;}\right.$the straight distance from the tip of the upper jaw to the fork in the tail), and can survive for more than 40 yr (Gunn et al. 2008).

SBT are targeted by fisheries such as the Japanese longline fleets in their open-ocean foraging habitat. The economic importance of the species is similar to that of Pacific and Atlantic bluefin tunas (T. orientalis and T. thynnus), the flesh of which earns a high price in the Japanese market. Since 1994, SBT have been managed internationally by the Commission for the Conservation of Southern Bluefin Tuna (CCSBT) (CCSBT 2015). The SBT stock is currently estimated to be depleted, and the species has been classified as critically endangered in the red list of the International Union for Conservation of Nature (IUCN 2011). However, in 2011, the CCSBT implemented a management procedure that was an adaptive rebuilding strategy to set a catch limit. The management procedure was fully tested in advance through simulations using a wide range of uncertainties in stock dynamics, with the goal of helping the species' stock reach the interim rebuilding target of $20 \%$ of the original spawning stock biomass (Hillary et al. 2015). A slight recovery of the spawning stock has recently been observed (CCSBT 2015).

In recent years, electronic tags have revealed important characteristics of SBT migration and behavior (Gunn \& Block 2001, Patterson et al. 2008). Because the vast amount of electronic tag data has generated several hypotheses concerning the interactions between SBT behavior and environmental factors, interest in interactions with its prey has been increasing (Patterson et al. 2008, Bestley et al. 2009). Prey of SBT in the open ocean around southern Australia and west of South Africa have been investigated by Serventy (1956) and Talbot \& Penrith
(1963), respectively, using stomach contents. Prey of SBT in the area around Tasmania have been analyzed in detail by Young et al. (1997). However, because time, space, and the number of samples investigated have been limited, the foraging ecology of SBT in the open ocean is still inadequately known.

To provide more comprehensive information, we investigated the foraging ecology of SBT in their openocean feeding grounds by analyzing stomach content samples collected over 15 yr from more than 4000 individuals. Based on these data, we describe linkages between SBT and prey animals in the food webs of the temperate waters in the southern hemisphere.

\section{MATERIALS AND METHODS}

\section{Stomach content sampling}

Stomach contents of SBT were sampled at sea by scientific observers on Japanese longline vessels. During the bleeding process, water is forced through the body cavity under pressure that is applied before freezing of fish onboard, and this can sometimes lead to eversion of the stomach. Initially, observers collected the whole stomach and did not sample from SBT that 'vomited' any part of their stomach contents, but subsequently they also collected stomach contents if the SBT vomited those contents. The observers positioned a scoop net with a $2.5 \mathrm{~mm}$ mesh before the mouth to collect the stomach contents. The mouth and gills were also checked for the presence of prey. The stomach or its contents were placed in a plastic bag, a waterproof label was attached, and the sample bag was then frozen. Observers recorded the FL $(\mathrm{cm})$, weight of the gilled and gutted fish $(\mathrm{kg})$, sex of the fish, the latitude, the longitude, and the sea surface temperature (SST) measured by the vessel at the onset of line setting for each longline operation.

In the laboratory, samples were thawed sufficiently to separate individual prey. All the stomach contents were visually identified to the lowest possible taxon. Identification using cephalopod mandibles was not attempted. The degree of digestion of each item was classified into 4 stages, from the least to most digested (stages A to D), using the criteria in Table S1 in the Supplement at www.int-res.com/articles/suppl/ m555p203_supp.pdf. All prey in a stomach were grouped by taxon and digestion stage, placed on a plastic tray separately for each group, and then photographed. Bait used for the longline operation was recorded but excluded from the data analysis. The bait was identified based on the species, size, color, 
and presence of a scar from the hook, and was later confirmed using the list of bait species used in the longline operation recorded by the observer. Prey in each group were counted and weighed to a resolution of $0.01,0.10$, and $1.00 \mathrm{~g}$ for specimens weighing up to $1 \mathrm{~g}$, up to $10 \mathrm{~g}$, and more than $10 \mathrm{~g}$, respectively. Cephalopods were counted based on the mantle or the head and arms, but when only mandibles were left in heavily digested individuals, the total number of mandibles was divided by 2 to estimate the number of individuals. Fish were counted based on their bodies, but for myctophid fish with heavily digested bodies that were not countable, the number of stomachs or otoliths was counted and then (for otoliths) divided by 2 .

\section{Data analyses}

Prey importance was expressed in terms of the proportion of the total weight of prey ( $\% \mathrm{~W})$, of the total number $(\% \mathrm{~N})$, and of the number of samples in which the prey occurred (\%O) (Hyslop 1980). We mainly used \%W to represent the importance of the energy gain for SBT provided by a given prey group. A concern was that a small number of stomachs containing an extremely large amount of prey would have a large influence on the $\% \mathrm{~W}$, which was calculated from pooled data. We therefore obtained 95\% confidence intervals by resampling 1000 times for $\% \mathrm{~W}, \% \mathrm{~N}$, and $\% \mathrm{O}$ via bootstrapping. If a small number of stomachs did have a large influence on the results, the confidence interval would be wide. In addition, we calculated the percent mean proportion by weight $(\% \mathrm{MW})$ and the percent mean proportion by number $(\% \mathrm{MN})$, based on the prey composition of individual SBT (Chipps \& Garvey 2007).

We assessed whether the number of stomachs examined was sufficient to capture prey diversity based on the cumulative prey curves as a function of the number of SBT stomachs (Ferry \& Cailliet 1996). We randomly sampled stomachs that contained prey by bootstrapping 1000 times. The number of unique prey items that occurred was calculated for each dataset. The probability that the slope of the regression line for the last 4 points in the cumulative prey curve did not differ significantly from 0 (i.e. that additional samples would not significantly increase the sampling effectiveness) was tested using Student's $t$ test (Bizzarro et al. 2007). This method depends on grouping of the prey items to be used in the data analysis. We used 62 prey items that could be classified to the family level or a higher level if no family level was identified, and that excluded unidentified prey, parasites, and non-animal specimens.

Sampling areas between $30^{\circ}$ and $50^{\circ} \mathrm{S}$ were divided into 3 groups based on the longitude: areas between $20^{\circ} \mathrm{W}$ and $60^{\circ} \mathrm{E}$ were defined as 'Cape' (the southern coast of Africa), those from $60^{\circ}$ to $140^{\circ} \mathrm{E}$ were defined as 'southeastern Indian Ocean', and those from $140^{\circ}$ to $160^{\circ} \mathrm{E}$ were defined as 'Tasmania' (Fig. 1). The weight composition of the prey was investigated in each of the 3 sampling areas by pooling data into 6 variables: SBT size (in $10 \mathrm{~cm}$ bins based on FL), SST (in bins of $1^{\circ} \mathrm{C}$ ), sampling year, sampling month, latitude (in $1^{\circ}$ bins), and longitude (in $10^{\circ}$ bins). Prey in digestion stage $\mathrm{D}$ were excluded. The data from SBT individuals sampled in the same longline operation were assumed to be independent of each other. No violation of independence was detected, confirming that the diet compositions were similar between 2 datasets: one dataset comprised of all the data, and the other dataset comprised only 1 SBT selected from each of the longline operations (i.e. SBT individuals were independent of each other in terms of longline operation).

To visualize the multivariate data, we used nonmetric multi-dimensional scaling (nMDS) (Clarke \& Warwick 2001). Since the prey composition differed among the 3 areas, we performed nMDS separately

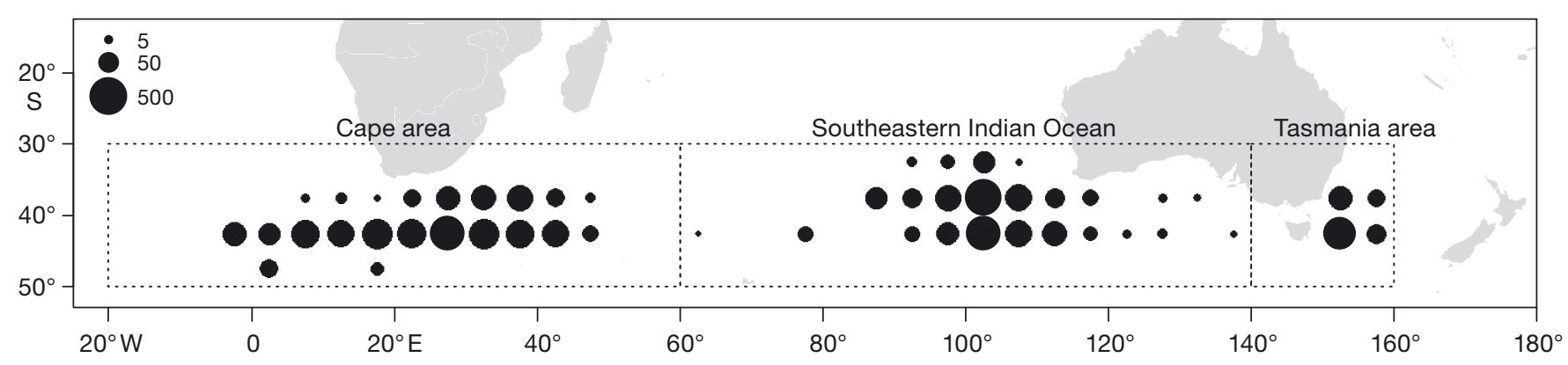

Fig. 1. Numbers of southern bluefin tuna with stomachs that contained natural prey (i.e. not bait, parasites, or marine debris) in $5^{\circ}$ latitude and longitude bins. The total sample size was 4649 
for each area. Prey in digestion stage D were excluded from the analysis, and we focused on the most important prey items (i.e. those with $\% \mathrm{~W}>3 \%$ ) for 6 fish groups (Nomeidae, Bramidae, other Perciformes, Alepisaurus, Paralepididae, and other teleosts), and 3 cephalopod groups (Ommastrephidae, Lycoteuthidae, and other Teuthida). Argonautids were also included although $\% \mathrm{~W}$ was $<3 \%$, since they were a characteristic prey item in the Tasmania area. Lycoteuthids were first identified in 2004. As their prevalence in earlier samples is unknown and they have been a characteristic prey in this area since that time, data for nMDS in the Cape area were limited to the years from 2004 onwards.

In stomach contents analysis, nMDS compares the variance in prey composition among groups to that within groups. Therefore, prey composition was needed for individual SBT or small groups of SBT. However, the fact that the SBT stomachs examined in the present study had only 1 item (prey type) in most cases (see 'Results' for details) would lead to an anomalous composition (e.g. extreme values such as $100 \%$ for only 1 item found and $0 \%$ for absent items) and result in a large variance. SBT individuals caught in the same longline operation were not an appropriate choice for a small group because the SBT catch rate was low, and a longline operation can extend more than $100 \mathrm{~km}$. Instead, we created subsets of the data by means of bootstrap sampling (with 50 iterations) for the nMDS analysis. The SBT that were grouped into the variables classes were randomly selected; the number of random selections equaled the number of SBT in the original dataset for each class.

We used the vegan package for $\mathrm{R}$ (https://cran.rproject.org/web/packages/vegan/index.html) for the nMDS analysis. Prey composition data were standardized using the Wisconsin double-standardization method, and then the Bray-Curtis dissimilarity index was calculated (Clarke \& Warwick 2001). We used the metaMDS function for vegan and started the nMDS analysis several times at random starting points to increase the likelihood of obtaining a globally optimal solution. We used the SIMPER (similarity percentage) function for vegan to identify the prey item with the greatest influence and its contribution to the Bray-Curtis dissimilarity index (Clarke \& Warwick 2001). We also used the adonis function (analysis of variance using distance matrices) for vegan to perform a permutation test with pseudo- $F$ ratios and identify statistically significant relationships between prey composition and the causal variables.

We used version 3.1.2 of R ( $\mathrm{R}$ Development Core Team 2014) for the data analysis.

\section{RESULTS}

Among samples from 5364 SBT, a total of 4649 SBT-2338 in the Cape, 1826 in the southeastern Indian Ocean, and 485 in the Tasmania areas - were found with natural prey (i.e. not bait, parasites, or marine debris). Another 36 stomachs contained parasites or marine debris only (Fig. 1, Table 1). The 5364 samples comprised 1997 SBT for which whole stomachs were sampled and 3367 SBT for which only stomach contents were sampled. In the 1997 samples from which the whole stomach was collected, 453 $(22.7 \%)$ were empty (no natural prey). Samples were collected mainly from 1999 to 2013, and the sample collection period differed among the areas. The main sampling months were from May to July in the Cape area, from August to December in the southeastern Indian Ocean, and from April to June in the Tasmania area. The slopes of the regression lines for the last

Table 1. Number of southern bluefin tuna analyzed to determine their stomach contents, by year and month, for the 3 study areas. Data are for tuna with natural prey (i.e. not bait, parasites, or marine debris) present in their stomach

\begin{tabular}{|c|c|c|c|c|}
\hline $\begin{array}{l}\text { Year/ } \\
\text { month }\end{array}$ & Cape & $\begin{array}{l}\text { Southeastern } \\
\text { Indian Ocean }\end{array}$ & Tasmania & Total \\
\hline 1998 & - & 7 & - & 7 \\
\hline 1999 & 7 & 229 & 139 & 375 \\
\hline 2000 & 89 & 90 & 56 & 235 \\
\hline 2001 & 153 & 27 & 58 & 238 \\
\hline 2002 & 193 & 14 & 44 & 251 \\
\hline 2003 & 167 & 118 & 122 & 407 \\
\hline 2004 & 265 & 165 & - & 430 \\
\hline 2005 & 319 & 195 & 23 & 537 \\
\hline 2006 & 468 & 225 & 20 & 713 \\
\hline 2007 & 193 & 376 & - & 569 \\
\hline 2008 & 125 & 97 & 1 & 223 \\
\hline 2009 & 85 & 146 & - & 231 \\
\hline 2010 & - & 57 & 14 & 71 \\
\hline 2011 & 103 & 40 & - & 143 \\
\hline 2012 & 66 & 40 & 8 & 114 \\
\hline 2013 & 105 & - & - & 105 \\
\hline Jan & 3 & - & - & 3 \\
\hline Feb & - & - & - & 0 \\
\hline Mar & - & - & - & 0 \\
\hline Apr & 39 & - & 82 & 121 \\
\hline May & 508 & - & 148 & 656 \\
\hline June & 927 & 17 & 252 & 1196 \\
\hline July & 470 & 58 & 3 & 531 \\
\hline Aug & 96 & 713 & - & 809 \\
\hline Sep & 37 & 294 & - & 331 \\
\hline Oct & 71 & 168 & - & 239 \\
\hline Nov & 75 & 362 & - & 437 \\
\hline Dec & 112 & 214 & - & 326 \\
\hline Total & 2338 & 1826 & 485 & 4649 \\
\hline
\end{tabular}


4 points in the cumulative sampling curves did not differ significantly from $0(\mathrm{p}>0.05)$ for the whole study area or for each individual area (Fig. 2); thus, the numbers of SBT examined were sufficient for our analysis. The number of unique prey items per SBT stomach ranged from 1 to 10 , with 1 item being most common, and the frequency then decreasing rapidly with increasing number of prey items (Table 2).

The confidence interval for \%W was small enough to confirm that \%W was not severely influenced by a small number of SBT individuals with anomalously large stomach contents (Table S2 in the Supplement. The \%MW values differed from the $\% \mathrm{~W}$ values and had large standard deviations, a reflection of the fact that the prey composition of individual SBT took on extreme values (such as
$100 \%$ for the 1 item found and $0 \%$ for absent items) because the number of prey types in individual SBTs was typically 1 . The \%MW values of the types of prey that were small in terms of weight but that occurred frequently (e.g. crustaceans and Salpida) were larger than the $\% \mathrm{~W}$ values.

Items found in SBT stomachs included 62 types of prey at the family or higher taxonomic level, 3 types of parasites (Nematoda, Torematoda, and Pennella), and marine debris (Table 3). By weight, the stomach contents comprised $51 \%$ cephalopods and $46 \%$ teleosts. Dominant cephalopods were Ommastrephidae $(18 \%)$, Lycoteuthidae $(12 \%)$, and unidentified cephalopods (18\%; including unidentified Teuthida and unidentified Octopoda). Most of the unidentified cephalopods were probably ommastrephids based on the

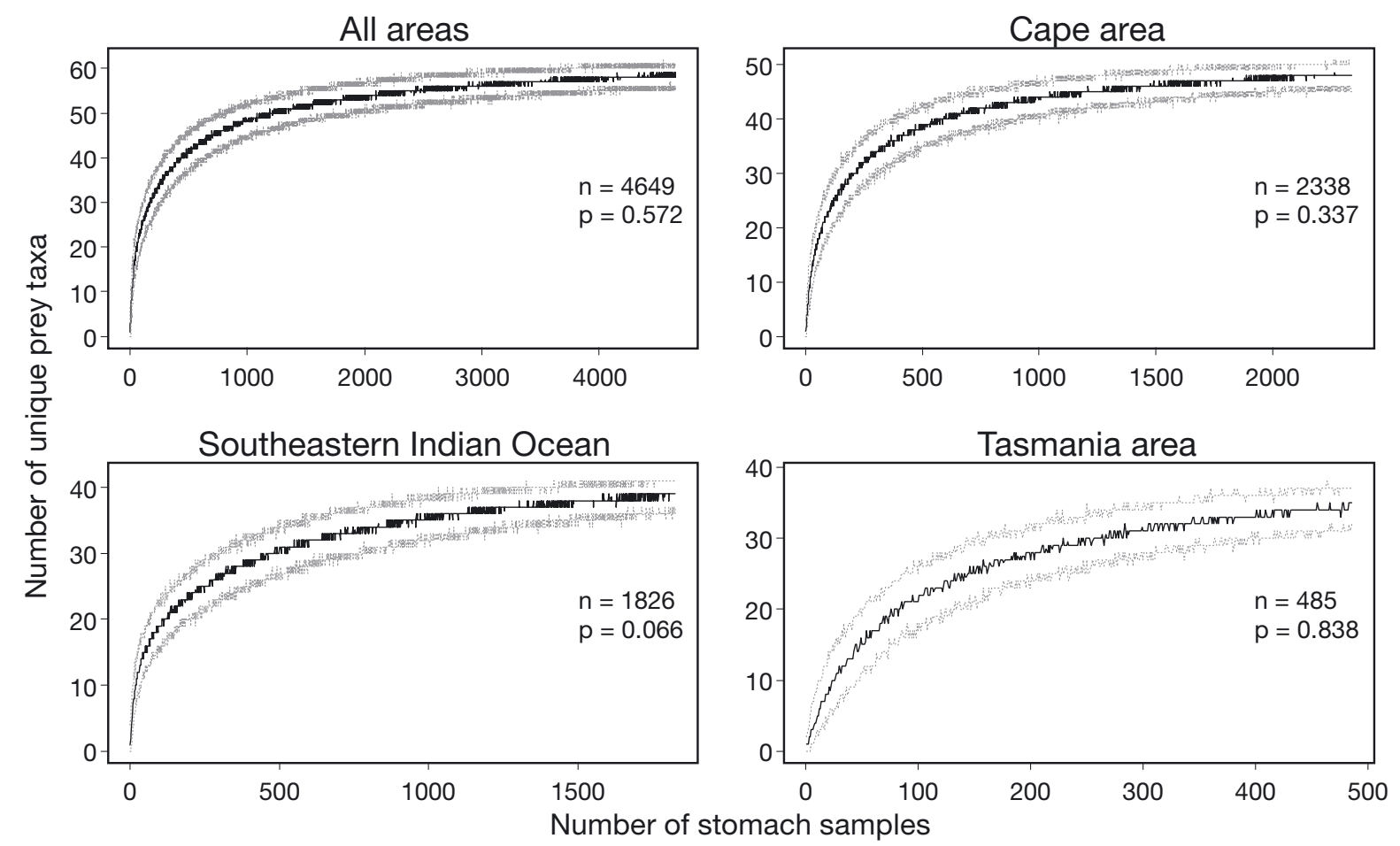

Fig. 2. Cumulative prey curves for the stomachs of southern bluefin tuna for the whole study area and for the 3 individual areas. In these graphs, $p$ is the probability that the slope of the linear regression for the last 4 points in the curve equals 0 .

The middle, lower and upper lines represent the median and the 5th and 95th percentiles, respectively

Table 2. Number of unique prey types per stomach of southern bluefin tuna. Data are for tuna with natural prey (i.e. not bait, parasites, or marine debris) present in their stomach. The prey was classified to the family level or higher and excluded others or unknown. Total number is 4551

\begin{tabular}{|lccccccccccc}
\hline $\begin{array}{l}\text { Number of unique } \\
\text { prey types per stomach }\end{array}$ & 1 & 2 & 3 & 4 & 5 & 6 & 7 & 8 & 9 \\
\hline $\begin{array}{l}\text { Frequency } \\
\text { Proportion of total }\end{array}$ & 1782 & 1402 & 723 & 343 & 162 & 71 & 40 & 17 & 10 \\
$0.2 \%$ & $30.8 \%$ & $15.9 \%$ & $7.5 \%$ & $3.6 \%$ & $1.6 \%$ & $0.9 \%$ & $0.4 \%$ & $0.2 \%$ & $0.0 \%$ \\
\hline
\end{tabular}


Table 3. Prey list of southern bluefin tuna Thunnus maccoyii for the whole study area and for the 3 areas. W, N, and O are the weight $(\mathrm{g})$, number of individuals, and number of southern bluefin tuna stomachs in which the prey item was found; \% W, \% and $\% \mathrm{O}$ are the corresponding proportions of the totals of natural preys (i.e. not parasite, non-animal or marine debris). Severely digested prey (digestion stage D) is included. Total number of stomachs was 4649 for natural prey. An additional 36 stomachs containing only parasites, non-animal, or marine debris were also included

\begin{tabular}{|c|c|c|c|c|c|c|c|c|c|}
\hline Taxon & $\mathrm{W}$ & $\mathrm{N}$ & $\mathrm{O}$ & $\% \mathrm{~W}$ & $\% \mathrm{~N}$ & $\% \mathrm{O}$ & $\begin{array}{l}\% W \\
\text { Cape }\end{array}$ & $\begin{array}{c}\text { \%W SE } \\
\text { Indian Ocean }\end{array}$ & $\begin{array}{c}\% \mathrm{~W} \\
\text { Tasmania }\end{array}$ \\
\hline CHORDATA & 411871 & 38109 & 2949 & 46.5 & 40.1 & 63.4 & 43.5 & 51.6 & 58.3 \\
\hline Teleostei & 409329 & 32447 & 2837 & 46.2 & 34.2 & 61.0 & 43.3 & 51.0 & 58.2 \\
\hline Perciformes & 166543 & 1675 & 531 & 18.8 & 1.8 & 11.4 & 19.7 & 15.7 & 21.7 \\
\hline Nomeidae & 73079 & 1049 & 350 & 8.3 & 1.1 & 7.5 & 8.7 & 8.8 & 1.2 \\
\hline Cubiceps caeruleus & 65154 & 965 & 327 & 7.4 & 1.0 & 7.0 & 7.6 & 8.3 & 0.8 \\
\hline Bramidae & 53843 & 139 & 94 & 6.1 & 0.1 & 2.0 & 8.0 & 2.1 & 2.1 \\
\hline Brama sp. & 7900 & 5 & 5 & 0.9 & 0.0 & 0.1 & 1.3 & 0.0 & \\
\hline Pterycombus petersii & 1165 & 9 & 9 & 0.1 & 0.0 & 0.2 & 0.0 & 0.4 & \\
\hline Scombridae & 14950 & 24 & 24 & 1.7 & 0.0 & 0.5 & 1.2 & & 14.0 \\
\hline Katsuwonus pelamis & 6612 & 11 & 11 & 0.7 & 0.0 & 0.2 & 0.9 & & 2.4 \\
\hline Thunnus sp. & 918 & 1 & 1 & 0.1 & 0.0 & 0.0 & & & 1.7 \\
\hline Auxis rochei & 237 & 2 & 2 & 0.0 & 0.0 & 0.0 & & & 0.4 \\
\hline Centrolophidae & 10945 & 18 & 10 & 1.2 & 0.0 & 0.2 & 0.6 & 3.2 & \\
\hline Hyperoglyphe moselii & 2776 & 3 & 1 & 0.3 & 0.0 & 0.0 & & 1.2 & \\
\hline Tetragonurus cuvieri & 6218 & 15 & 12 & 0.7 & 0.0 & 0.3 & 0.6 & 0.6 & 2.0 \\
\hline Gempylidae & 3191 & 12 & 7 & 0.4 & 0.0 & 0.2 & 0.2 & 0.8 & 0.7 \\
\hline Carangidae & 1692 & 21 & 22 & 0.2 & 0.0 & 0.5 & 0.1 & & 1.7 \\
\hline Decapterus sp. & 758 & 11 & 11 & 0.1 & 0.0 & 0.2 & 0.0 & 0.1 & 0.6 \\
\hline Pentacerotidae & 1415 & 386 & 16 & 0.2 & 0.4 & 0.3 & 0.2 & 0.0 & \\
\hline Mugilidae & 1090 & 8 & 8 & 0.1 & 0.0 & 0.2 & 0.2 & & \\
\hline Echeneididae & 105 & 1 & 1 & 0.0 & 0.0 & 0.0 & & 0.0 & \\
\hline Uranoscopidae & 17 & 2 & 1 & 0.0 & 0.0 & 0.0 & & & 0.0 \\
\hline Myctophiformes & 143321 & 17348 & 1010 & 16.2 & 18.3 & 21.7 & 14.2 & 23.8 & 5.7 \\
\hline Alepisauridae & 55397 & 590 & 475 & 6.3 & 0.6 & 10.2 & 3.8 & 13.3 & 3.3 \\
\hline Alepisaurus ferox & 8276 & 54 & 47 & 0.9 & 0.1 & 1.0 & 0.4 & 2.2 & 2.1 \\
\hline Alepisaurus brevirostris & 2254 & 10 & 9 & 0.3 & 0.0 & 0.2 & 0.2 & 0.5 & 0.2 \\
\hline Paralepididae & 58697 & 878 & 394 & 6.6 & 0.9 & 8.5 & 6.0 & 9.5 & 1.6 \\
\hline Paralepis sp. & 33812 & 232 & 131 & 3.8 & 0.2 & 2.8 & 3.9 & 4.5 & \\
\hline Paralepis atlantica & 9742 & 76 & 40 & 1.1 & 0.1 & 0.9 & 1.1 & 1.2 & \\
\hline Omosudis lowei & 475 & 8 & 8 & 0.1 & 0.0 & 0.2 & 0.0 & 0.0 & 0.8 \\
\hline Notosudidae & 2172 & 15 & 15 & 0.2 & 0.0 & 0.3 & 0.3 & 0.2 & \\
\hline Anotopterus pharao & 1694 & 5 & 1 & 0.2 & 0.0 & 0.0 & 0.3 & & \\
\hline Myctophidae & 24647 & 15851 & 253 & 2.8 & 16.7 & 5.4 & 3.8 & 0.9 & \\
\hline Synodontidae & 238 & 1 & 1 & 0.0 & 0.0 & 0.0 & 0.0 & & \\
\hline Tetraodontiformes & 961 & 26 & 14 & 0.1 & 0.0 & 0.3 & 0.0 & & 1.7 \\
\hline Tetraodontidae & 712 & 17 & 8 & 0.1 & 0.0 & 0.2 & & & 1.3 \\
\hline Triacanthodidae & 43 & 2 & 2 & 0.0 & 0.0 & 0.0 & 0.0 & & \\
\hline Lampriformes & 14669 & 44 & 43 & 1.7 & 0.0 & 0.9 & 2.1 & 0.6 & 0.7 \\
\hline Reqalecus sp. & 3356 & 10 & 10 & 0.4 & 0.0 & 0.2 & 0.5 & 0.1 & 0.7 \\
\hline Trachipteridae & 607 & 1 & 1 & 0.1 & 0.0 & 0.0 & 0.1 & & \\
\hline Beloniformes & 3657 & 57 & 36 & 0.4 & 0.1 & 0.8 & 0.1 & 0.0 & 5.4 \\
\hline Scomberesocidae & 761 & 20 & 12 & 0.1 & 0.0 & 0.3 & 0.0 & & 1.0 \\
\hline Exocoetidae & 299 & 2 & 2 & 0.0 & 0.0 & 0.0 & 0.0 & & \\
\hline Belonidae & 321 & 2 & 1 & 0.0 & 0.0 & 0.0 & & & 0.6 \\
\hline Hemiramphidae & 216 & 5 & 4 & 0.0 & 0.0 & 0.1 & & 0.0 & 0.3 \\
\hline Beryciformes & 2099 & 24 & 16 & 0.2 & 0.0 & 0.3 & 0.2 & 0.5 & \\
\hline Beryx sp. & 1047 & 20 & 14 & 0.1 & 0.0 & 0.3 & 0.2 & & \\
\hline Diretmidae & 1052 & 4 & 2 & 0.1 & 0.0 & 0.0 & & 0.5 & \\
\hline Stomiiformes & 1450 & 4053 & 50 & 0.2 & 4.3 & 1.1 & 0.1 & 0.5 & \\
\hline Sternoptychidae & 1440 & 4041 & 48 & 0.2 & 4.3 & 1.0 & 0.1 & 0.5 & \\
\hline Gonostomatidae & 9 & 11 & 1 & 0.0 & 0.0 & 0.0 & & 0.0 & \\
\hline Clupeiformes & 4384 & 59 & 42 & 0.5 & 0.1 & 0.9 & 0.6 & 0.3 & 0.3 \\
\hline Sardinops sp. & 1014 & 19 & 6 & 0.1 & 0.0 & 0.1 & 0.0 & 0.3 & \\
\hline Etrumeus sp. & 188 & 1 & 1 & 0.0 & 0.0 & 0.0 & 0.0 & & \\
\hline Zeiformes & 56 & 3 & 3 & 0.0 & 0.0 & 0.1 & 0.0 & 0.0 & 0.0 \\
\hline Oreosoma atlanticum & 56 & 3 & 3 & 0.0 & 0.0 & 0.1 & 0.0 & 0.0 & 0.0 \\
\hline Sygnathiformes & 957 & 58 & 25 & 0.1 & 0.1 & 0.5 & 0.1 & 0.2 & 0.0 \\
\hline Macrorhamphosidae & 954 & 57 & 24 & 0.1 & 0.1 & 0.5 & 0.1 & 0.2 & \\
\hline Notopogon sp. & 580 & 45 & 18 & 0.1 & 0.0 & 0.4 & 0.1 & 0.1 & \\
\hline Hippocampus sp. & 3 & 1 & 1 & 0.0 & 0.0 & 0.0 & & & 0.0 \\
\hline Unidentified teleosts & 71232 & 9100 & 1665 & 8.0 & 9.6 & 35.8 & 6.2 & 9.3 & 22.8 \\
\hline
\end{tabular}


Table 3 (continued)

\begin{tabular}{|c|c|c|c|c|c|c|c|c|c|}
\hline Taxon & W & $\mathrm{N}$ & $\mathrm{O}$ & $\% \mathrm{~W}$ & $\% \mathrm{~N}$ & $\% \mathrm{O}$ & $\begin{array}{l}\% \mathrm{~W} \\
\text { Cape }\end{array}$ & $\begin{array}{c}\% \text { W SE } \\
\text { Indian Ocean }\end{array}$ & $\begin{array}{c}\% \mathrm{~W} \\
\text { Tasmania }\end{array}$ \\
\hline Thaliacea & 2542 & 5662 & 382 & 0.3 & 6.0 & 8.2 & 0.2 & 0.6 & 0.1 \\
\hline Salpida & 1658 & 4937 & 348 & 0.2 & 5.2 & 7.5 & 0.1 & 0.5 & 0.1 \\
\hline Pyrosomatida & 883 & 725 & 41 & 0.1 & 0.8 & 0.9 & 0.1 & 0.0 & \\
\hline MOLLUSCA & 449654 & 34733 & 3622 & 50.8 & 36.6 & 77.9 & 54.2 & 45.7 & 34.6 \\
\hline Cephalopoda & 449038 & 33566 & 3538 & 50.7 & 35.3 & 76.1 & 54.2 & 45.5 & 34.5 \\
\hline Teuthida & 436233 & 32762 & 3360 & 49.3 & 34.5 & 72.3 & 53.9 & 44.3 & 18.6 \\
\hline Ommastrephidae & 157854 & 1883 & 501 & 17.8 & 2.0 & 10.8 & 17.8 & 21.1 & 4.1 \\
\hline Lycoteuthidae & 109192 & 1753 & 267 & 12.3 & 1.8 & 5.7 & 18.0 & 0.5 & \\
\hline Lycoteuthis lorigera & 4981 & 56 & 12 & 0.6 & 0.1 & 0.3 & 0.7 & 0.3 & \\
\hline Onychoteuthidae & 16847 & 227 & 84 & 1.9 & 0.2 & 1.8 & 2.7 & 0.2 & 0.1 \\
\hline Moroteuthis ingens & 14120 & 170 & 51 & 1.6 & 0.2 & 1.1 & 2.3 & 0.0 & \\
\hline Cranchiidae & 48 & 27 & 15 & 0.0 & 0.0 & 0.3 & 0.0 & & 0.0 \\
\hline Histioteuthidae & 809 & 8 & 8 & 0.1 & 0.0 & 0.2 & 0.1 & & \\
\hline Octopoda & 9789 & 348 & 170 & 1.1 & 0.4 & 3.7 & 0.2 & 0.1 & 15.6 \\
\hline Argonautidae & 9042 & 316 & 145 & 1.0 & 0.3 & 3.1 & 0.1 & & 15.6 \\
\hline Unidentified Cephalopoda & 3016 & 456 & 84 & 0.3 & 0.5 & 1.8 & 0.1 & 1.1 & 0.3 \\
\hline Gastropoda & 615 & 1167 & 335 & 0.1 & 1.2 & 7.2 & 0.0 & 0.2 & 0.0 \\
\hline Sorbeoconcha & 352 & 410 & 188 & 0.0 & 0.4 & 4.0 & 0.0 & 0.1 & 0.0 \\
\hline Carinariidae & 299 & 373 & 171 & 0.0 & 0.4 & 3.7 & 0.0 & 0.1 & 0.0 \\
\hline Atlantidae & 53 & 37 & 20 & 0.0 & 0.0 & 0.4 & 0.0 & 0.0 & \\
\hline Thecosomata & 263 & 752 & 172 & 0.0 & 0.8 & 3.7 & 0.0 & 0.1 & 0.0 \\
\hline Cavoliniidae & 263 & 752 & 172 & 0.0 & 0.8 & 3.7 & 0.0 & 0.1 & 0.0 \\
\hline Unidentified Gastropoda & 0 & 5 & 4 & 0.0 & 0.0 & 0.0 & 0.0 & 0.0 & 0.0 \\
\hline ARTHROPODA & 7988 & 20983 & 1148 & 0.9 & 22.1 & 24.7 & 0.6 & 1.2 & 2.6 \\
\hline Crustacea & 7988 & 20983 & 1148 & 0.9 & 22.1 & 24.7 & 0.6 & 1.2 & 2.6 \\
\hline Decapoda & 3050 & 2570 & 206 & 0.3 & 2.7 & 4.4 & 0.2 & 0.2 & 2.2 \\
\hline Funchalia sp. & 993 & 135 & 5 & 0.1 & 0.1 & 0.1 & 0.0 & & 1.6 \\
\hline Oplophoridae & 36 & 4 & 4 & 0.0 & 0.0 & 0.1 & & 0.0 & 0.1 \\
\hline (shrimp) & 1156 & 215 & 87 & 0.1 & 0.2 & 1.9 & 0.1 & 0.2 & 0.2 \\
\hline Brachyura & 850 & 2184 & 106 & 0.1 & 2.3 & 2.3 & 0.1 & 0.0 & 0.4 \\
\hline Anomura & 1 & 2 & 2 & 0.0 & 0.0 & 0.0 & 0.0 & & 0.0 \\
\hline Amphipoda & 4055 & 13314 & 940 & 0.5 & 14.0 & 20.2 & 0.3 & 0.8 & 0.2 \\
\hline Phronima sedentaria & 392 & 1315 & 246 & 0.0 & 1.4 & 5.3 & 0.0 & 0.1 & 0.1 \\
\hline Platyscelidae & 92 & 468 & 90 & 0.0 & 0.5 & 1.9 & 0.0 & 0.0 & 0.0 \\
\hline Platyscelus sp. & 26 & 148 & 25 & 0.0 & 0.2 & 0.5 & & 0.0 & 0.0 \\
\hline Phrosinidae & 142 & 242 & 51 & 0.0 & 0.3 & 1.1 & 0.0 & 0.0 & 0.0 \\
\hline Phrosina sp. & 49 & 97 & 24 & 0.0 & 0.1 & 0.5 & & 0.0 & 0.0 \\
\hline Hyperiidae & 18 & 139 & 30 & 0.0 & 0.1 & 0.6 & & 0.0 & \\
\hline Themisto sp. & 9 & 120 & 25 & 0.0 & 0.1 & 0.5 & 0.0 & & \\
\hline Brachyscelus sp. & 43 & 249 & 29 & 0.0 & 0.3 & 0.6 & 0.0 & 0.0 & 0.0 \\
\hline Pronoidae & 3 & 23 & 5 & 0.0 & 0.0 & 0.1 & 0.0 & 0.0 & 0.0 \\
\hline Euphausiacea & 84 & 692 & 24 & 0.0 & 0.7 & 0.5 & 0.0 & 0.0 & 0.0 \\
\hline Stomatopoda & 270 & 1402 & 14 & 0.0 & 1.5 & 0.3 & 0.0 & 0.1 & 0.0 \\
\hline Lophogastrida & 68 & 6 & 6 & 0.0 & 0.0 & 0.1 & & & 0.1 \\
\hline Gnathophausiidae & 68 & 6 & 6 & 0.0 & 0.0 & 0.1 & & & 0.1 \\
\hline Isopoda & 3 & 8 & 6 & 0.0 & 0.0 & 0.1 & & 0.0 & 0.0 \\
\hline Unidentified Crustacea & 458 & 2991 & 146 & 0.1 & 3.1 & 3.1 & 0.0 & 0.1 & 0.0 \\
\hline ANNELIDA & 18 & 81 & 31 & 0.0 & 0.1 & 0.7 & 0.0 & 0.0 & \\
\hline Polychaeta & 18 & 81 & 31 & 0.0 & 0.1 & 0.7 & 0.0 & 0.0 & \\
\hline CNIDARIA & 97 & 7 & 7 & 0.0 & 0.0 & 0.2 & 0.0 & & 0.0 \\
\hline Unknown & 10690 & 57 & 275 & 1.2 & 0.1 & 5.9 & 1.2 & 0.6 & 3.8 \\
\hline Other & 5129 & 1020 & 454 & 0.6 & 1.1 & 9.8 & 0.4 & 1.0 & 0.7 \\
\hline Total & 885447 & 94990 & & & & & 601076 & 230172 & 54199 \\
\hline Parasites & 314 & 3782 & 852 & & & & & & \\
\hline NEMATODA & 91 & 1814 & 277 & & & & & & \\
\hline Torematoda & 179 & 1467 & 471 & & & & & & \\
\hline Pennella sp. & 42 & 484 & 227 & & & & & & \\
\hline Unidentified parasites & 1 & 17 & 3 & & & & & & \\
\hline Non-animal & 716 & 36 & 33 & & & & & & \\
\hline Marine debris (plastic) & 767 & 133 & 140 & & & & & & \\
\hline
\end{tabular}


thick mantle muscle in these specimens and the way that digestion advanced (the mantle tended to be open in digested lycoteuthids). However, we treated these items as unidentified cephalopods in the subsequent analyses. Dominant teleosts were Nomeidae (8\%) (mainly Cubiceps caeruleus [7\%]), Paralepididae $(7 \%)$, Bramidae $(6 \%)$, Alepisauridae $(6 \%)$, and unidentified teleosts $(8 \%)$.

By numbers, $35 \%$ of prey items were cephalopods, $34 \%$ were teleosts, $22 \%$ were crustaceans, and $6 \%$ were Thaliacea (Table 3 ). The dominant cephalopods were ommastrephids $(2 \%)$, lycoteuthids $(2 \%)$, and unidentified cephalopods $(31 \%)$. The reason for the large proportion of unidentified cephalopods was the many mandibles that had accumulated in the stomachs. The dominant teleosts were myctophids (17\%), Stomiiformes (4\%), and unidentified teleosts $(10 \%)$. The dominant crustaceans were amphipods (14\%) and decapods (Brachyura; $2 \%$ ).

By occurrence, cephalopods composed $76 \%$, teleosts $61 \%$, crustaceans $25 \%$, Thaliacea $8 \%$, and Gastropoda $7 \%$ (Table 3 ). The dominant cephalopods were ommastrephids (11\%), lycoteuthids (6\%), and unidentified cephalopods (69\%). Dominant teleosts were Alepisauridae (10\%), Paralepididae (9\%), Nomeidae (8\%), Myctophidae (5\%), and unidentified teleosts $(36 \%)$. The dominant crustaceans were Amphipoda (20\%).

\section{Prey composition as a function of the main variables}

Cephalopods and teleosts were present in roughly equal weight proportions, and together accounted for almost all of the prey weight in all 3 areas (Fig. 3). In the detailed classification at the family level, several characteristics differed among the areas. Of the cephalopods, lycoteuthids accounted for more than $20 \%$ of the total prey weight in the Cape area, but negligible amounts in the other areas. Similarly, argonautids were common in the Tasmania area but negligible in the other areas. Of the teleosts, alepisaurids were more frequent in the southeastern Indian Ocean than in the other areas, whereas scombrids were much more frequent in the Tasmania area. Prey composition differed significantly among the 3 areas (Bray-Curtis dissimilarity index, adonis $\mathrm{p}<0.01)$.

Prey composition differed significantly for all 6 variables in each of the areas (adonis $\mathrm{p}<0.01$ ). For SBT size based on FL, prey composition was similar within each of the ranges between 80 and $110 \mathrm{~cm} \mathrm{FL}$

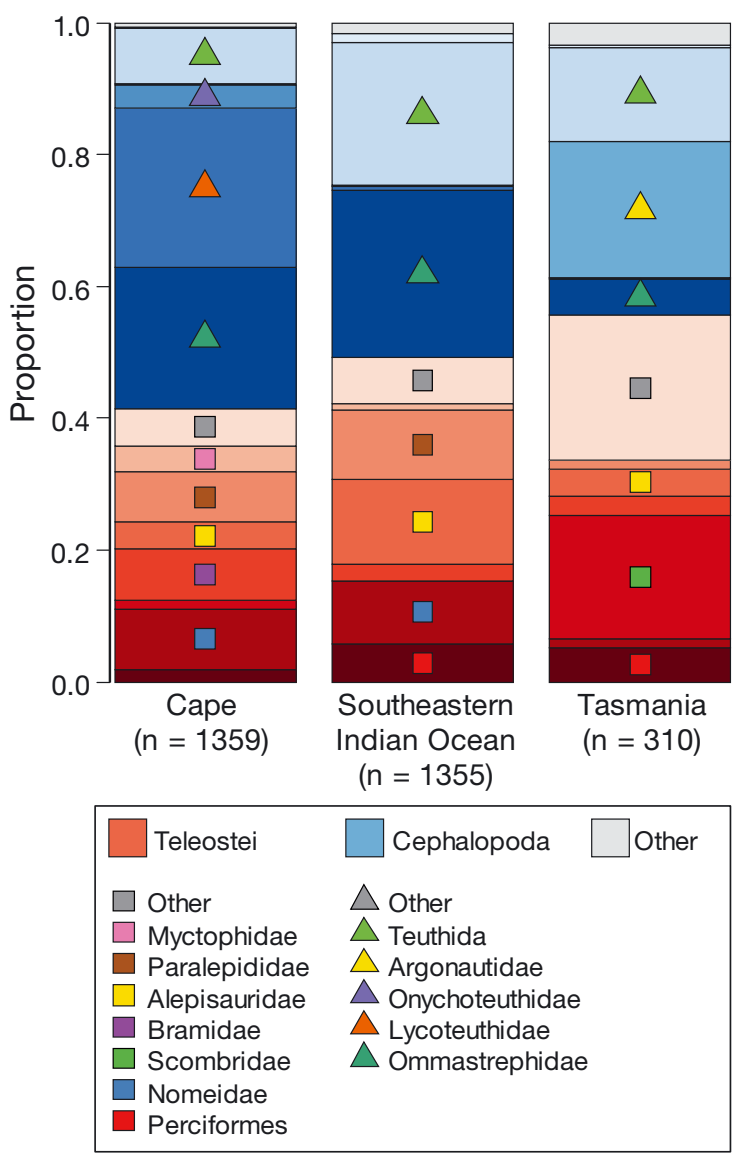

Fig. 3. Weight composition of the stomach contents of southern bluefin tuna in the 3 sampling areas. The numbers of sampled southern bluefin tuna with natural prey of digestion stage A, B or C in their stomachs (n) are shown below the graphs. Data for the Cape area were limited to after 2004, when lycoteuthids were first distinguished. Prey items with values of $>3 \%$ are shown with symbols

and between 120 and $180 \mathrm{~cm}$ FL in the southeastern Indian Ocean, and within each of the Cape and Tasmania areas (Fig. 4). Cephalopods were more abundant in small SBT from 80 to $110 \mathrm{~cm}$ FL (and also in the largest fish [190 cm FL], but there were only 6 individuals of this size) than in the other size categories in the southeastern Indian Ocean. The nMDS plot for the southeastern Indian Ocean showed a clear shift from left to right along axis 1 for the data points for SBT from 80 to $180 \mathrm{~cm}$ FL (Fig. 5). The SIMPER analysis showed that the largest contribution to the Bray-Curtis dissimilarity index was made by ommastrephids in most of the combinations (Table 4). Therefore, the shift in the nMDS plot appeared to be mostly due to differences in the ommastrephid proportion. However, the ommastrephid proportion was small for the small SBT $(<110 \mathrm{~cm}$ FL) in the Cape area. 

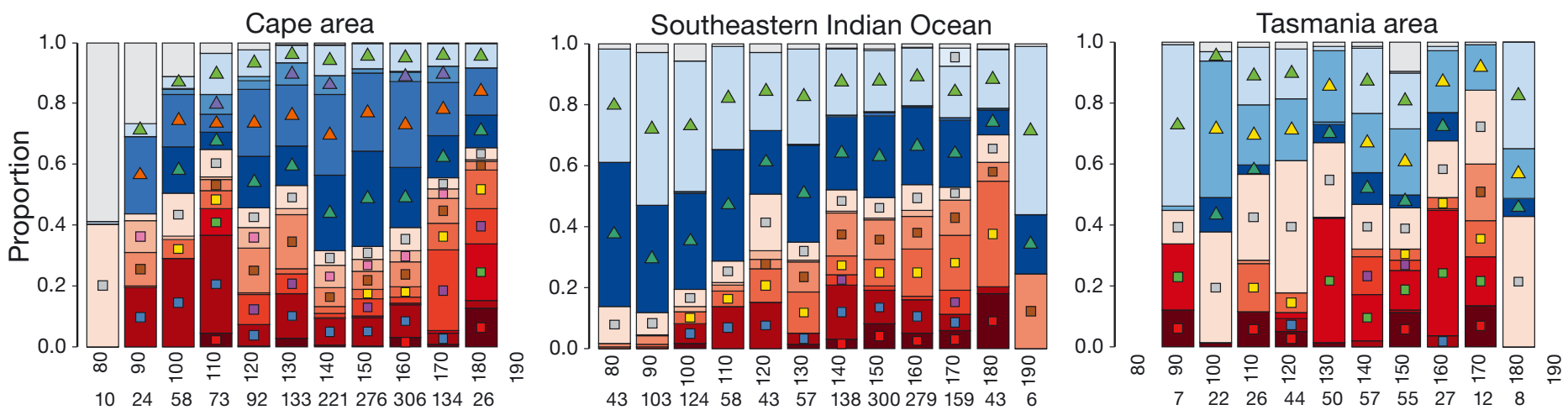

Fig. 4. Weight composition of the stomach contents of southern bluefin tuna by fork length (FL) in $10 \mathrm{~cm}$ bins for the 3 study areas. See legend in Fig. 3 for explanation of symbols. Numbers below FL represent the sample size. Compositions for FL

classes with $<5$ tuna sampled are not shown

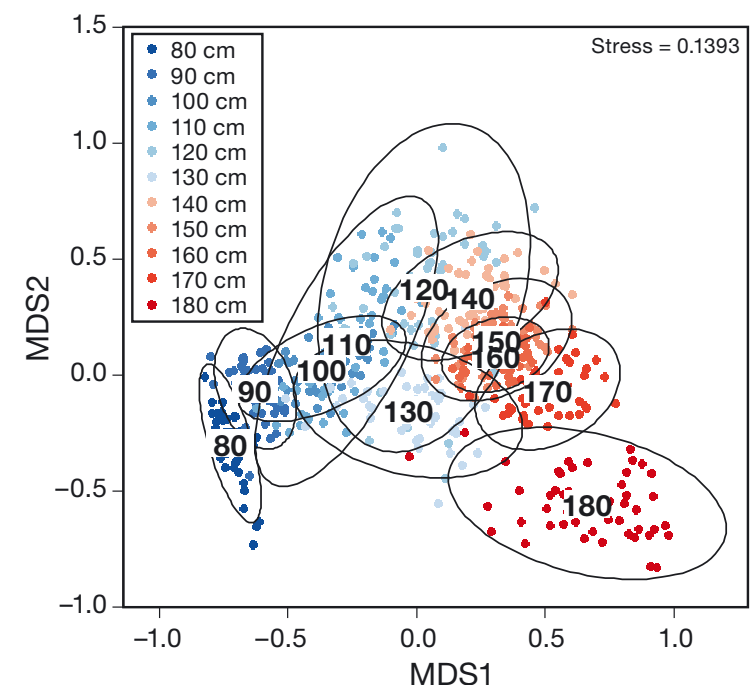

Fig. 5. Stomach composition of southern bluefin tuna in weight by fork length in $10 \mathrm{~cm}$ bins for tuna from the southeastern Indian Ocean. Ellipses represent the 95\% confidence interval. Stress is a goodness-of-fit statistic (smaller values represent a better fit). See Fig. S1 in the Supplement for data from the other areas
In terms of SST, cephalopods were the dominant prey (between 50 and $80 \%$ of the total weight) at SSTs ranging from 6 to $14^{\circ} \mathrm{C}$ in the Cape area (Fig. 6). Among the cephalopods, lycoteuthids dominated at SSTs of 6 to $8^{\circ} \mathrm{C}$, and were present at roughly the same levels as ommastrephids at SSTs of 9 to $10^{\circ} \mathrm{C}_{i}$ ommastrephids were the dominant prey at SSTs of 11 to $15^{\circ} \mathrm{C}$. The nMDS plot showed a clear shift from the center left to the upper central part of the plot as SST increased from 6 to $13^{\circ} \mathrm{C}$, and then shifted to the bottom right as SST increased to $18^{\circ} \mathrm{C}$ (Fig. 7). The SIMPER analysis showed that the largest contributors to the Bray-Curtis dissimilarity index were lycoteuthids or ommastrephids in most of the combinations (Table 5). SBT samples in the southeastern Indian Ocean came from a narrow range of SST (mostly from 10 to $13^{\circ} \mathrm{C}$ ), and as a result, a much smaller variation of the prey composition was observed (Fig. 6). In Tasmania, the prey composition at $13^{\circ} \mathrm{C}$ differed from those at 15 to $17^{\circ} \mathrm{C}$ because no Perciformes (mainly scombrid fish) were present at lower temperatures.

Table 4. Results of SIMPER analysis for prey weight composition in $10 \mathrm{~cm}$ fork length (FL) bins for southern bluefin tuna captured in the southeastern Indian Ocean. The lower left part of the table shows the prey with the greatest influence on the BrayCurtis dissimilarity index; the upper right part of the table shows the corresponding contribution. Underlined abbreviations represent prey with a contribution $>30 \%$. Ale, Alepisauridae; Nom, Nomeidae; Omm, Ommastrephidae

\begin{tabular}{|c|c|c|c|c|c|c|c|c|c|c|c|}
\hline FL bin $(\mathrm{cm})$ & 80 & 90 & 100 & 110 & 120 & 130 & 140 & 150 & 160 & 170 & 180 \\
\hline 80 & & 0.85 & 0.77 & 0.43 & 0.32 & 0.59 & 0.40 & 0.50 & 0.43 & 0.44 & 0.52 \\
\hline 90 & Omm & & 0.70 & 0.75 & 0.56 & 0.44 & 0.37 & 0.49 & 0.42 & 0.42 & 0.52 \\
\hline 100 & $\overline{\mathrm{Omm}}$ & $\underline{\mathrm{Omm}}$ & & 0.79 & 0.84 & 0.63 & 0.34 & 0.46 & 0.39 & 0.38 & 0.39 \\
\hline 110 & $\overline{\text { Nom }}$ & $\underline{\text { Nom }}$ & $\underline{\mathrm{Omm}}$ & & 0.53 & 0.38 & 0.40 & 0.50 & 0.43 & 0.44 & 0.51 \\
\hline 120 & $\overline{\mathrm{Omm}}$ & $\overline{\mathrm{Omm}}$ & $\overline{\mathrm{Omm}}$ & $\underline{\mathrm{Omm}}$ & & 0.72 & 0.44 & 0.52 & 0.45 & 0.46 & 0.44 \\
\hline 130 & $\overline{\mathrm{Omm}}$ & $\overline{\mathrm{Omm}}$ & $\overline{\mathrm{Omm}}$ & $\overline{\mathrm{Omm}}$ & $\underline{\mathrm{Omm}}$ & & 0.35 & 0.49 & 0.42 & 0.42 & 0.45 \\
\hline 140 & $\mathrm{Omm}$ & $\underline{\mathrm{Omm}}$ & Nom & $\mathrm{Omm}$ & $\mathrm{Omm}$ & $\underline{\mathrm{Omm}}$ & & 0.55 & 0.44 & 0.38 & 0.35 \\
\hline 150 & $\overline{\mathrm{Omm}}$ & $\overline{\mathrm{Omm}}$ & $\overline{\mathrm{Omm}}$ & $\overline{\mathrm{Omm}}$ & $\overline{\mathrm{Omm}}$ & $\overline{\mathrm{Omm}}$ & $\underline{\mathrm{Omm}}$ & & 0.51 & 0.28 & 0.58 \\
\hline 160 & $\overline{\mathrm{Omm}}$ & $\overline{\mathrm{Omm}}$ & $\overline{\mathrm{Omm}}$ & $\overline{\mathrm{Omm}}$ & $\overline{\mathrm{Omm}}$ & $\overline{\mathrm{Omm}}$ & $\overline{\mathrm{Omm}}$ & $\underline{\mathrm{Ale}}$ & & 0.31 & 0.48 \\
\hline 170 & $\overline{\mathrm{Omm}}$ & $\mathrm{Omm}$ & $\overline{\mathrm{Omm}}$ & $\mathrm{Omm}$ & $\overline{\mathrm{Omm}}$ & $\mathrm{Omm}$ & $\underline{\mathrm{Omm}}$ & $\overline{\mathrm{Omm}}$ & Omm & & 0.52 \\
\hline 180 & Ale & Ale & $\mathrm{Omm}$ & Ale & Ale & Ale & $\mathrm{Omm}$ & Omm & $\mathrm{Omm}$ & Omm & \\
\hline
\end{tabular}




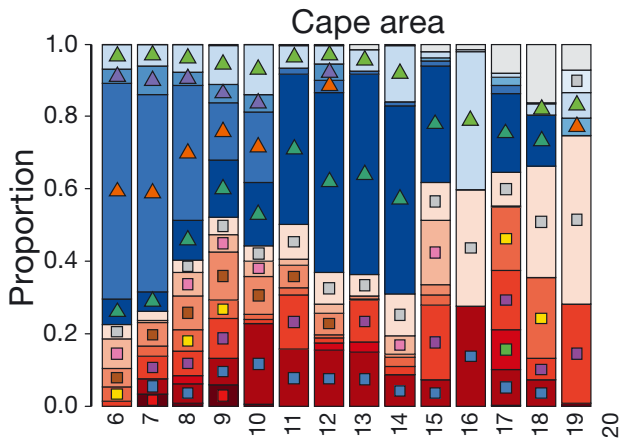

2610730926414450431004329181037128
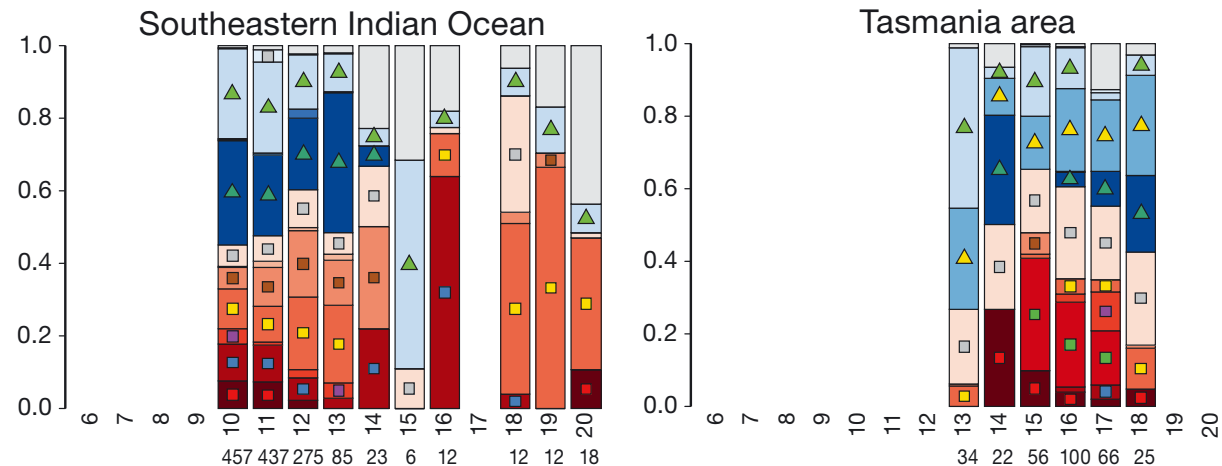

Fig. 6. Weight composition of the stomach contents of southern bluefin tuna by sea surface temperature (SST) in $1^{\circ} \mathrm{C}$ bins for the 3 study areas. See legend in Fig. 3 for explanation of symbols. Numbers below the SST represent the sample size. Compositions of SST bins with $<5$ tuna are not shown

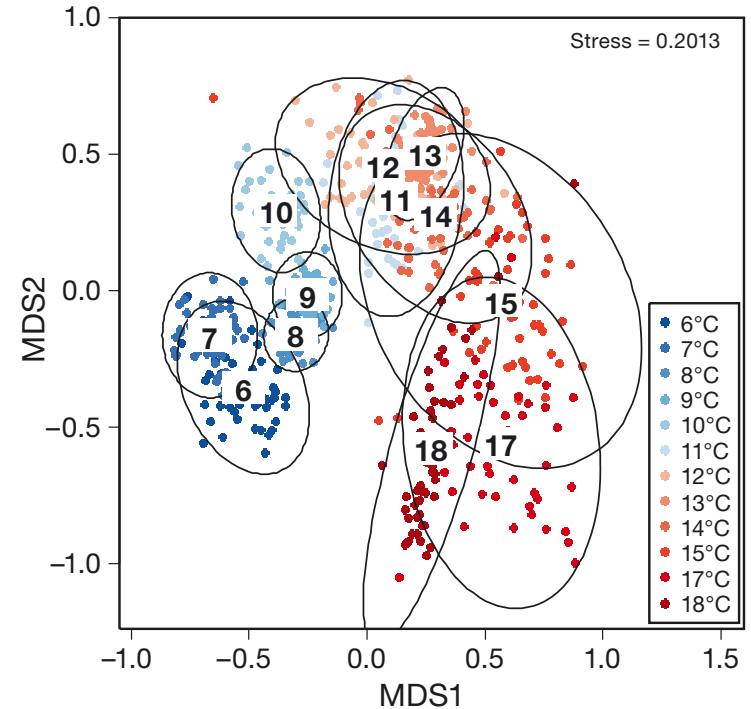

Fig. 7. Stomach composition of southern bluefin tuna in weight by sea surface temperature in $1^{\circ} \mathrm{C}$ bins for tuna from the Cape area. Ellipses represent the $95 \%$ confidence interval. Stress is a goodness-of-fit statistic (smaller values represent a better fit). See Fig. S2 in the Supplement for data from the other sampling areas
The prey composition showed no clear trend over time, but there were some changes (Fig. 8). The proportion of lycoteuthids in the Cape area was smaller in 2007 than in the other years; these animals were not included in the data from before 2004 because Lycoteuthidae were first identified in 2004. The proportion of cephalopods was higher from 2004 to 2006 in the Cape area and in 2004 in the southeastern Indian Ocean. The proportions of nomeid fish were higher from 2007 to 2009 in the Cape area.

The nMDS plots confirm that prey compositions showed no clear trend over time, such as a continuous shift (Fig. S3 in the Supplement). The SIMPER analysis shows that the largest contributors to differences in the Bray-Curtis dissimilarity index were lycoteuthids or ommastrephids in many years, but nomeid fish in 2007 and bramid fish in 2013 provided the dominant contribution to the index for the Cape area for most of the combinations (Table S3 in the Supplement). In Tasmania, 1999 was distinguished from the other years by the high contribution from argonautids.

Table 5. Results of SIMPER analysis for prey weight composition in $1{ }^{\circ} \mathrm{C}$ sea surface temperature (SST) bins for southern bluefin tuna captured in the Cape area. The lower left part of the table shows the prey with the greatest influence on the Bray-Curtis dissimilarity index; the upper right part of the table shows the corresponding contribution. Underlined abbreviations represent prey with a contribution $>30 \%$. Bra, Bramidae; Lyc, Lycoteuthidae; Nom, Nomeidae; Omm, Ommastrephidae; Tel, Teleostei

\begin{tabular}{|c|c|c|c|c|c|c|c|c|c|c|c|c|}
\hline $\mathrm{SST}\left({ }^{\circ} \mathrm{C}\right)$ & 6 & 7 & 8 & 9 & 10 & 11 & 12 & 13 & 14 & 15 & 17 & 18 \\
\hline 6 & & 0.61 & 0.34 & 0.27 & 0.26 & 0.42 & 0.45 & 0.52 & 0.45 & 0.48 & 0.32 & 0.57 \\
\hline 7 & Lyc & & 0.21 & 0.31 & 0.53 & 0.64 & 0.62 & 0.44 & 0.56 & 0.64 & 0.68 & 0.62 \\
\hline 8 & Lyc & Omm & & 0.59 & 0.41 & 0.42 & 0.40 & 0.45 & 0.46 & 0.38 & 0.39 & 0.37 \\
\hline 9 & $\overline{\mathrm{Omm}}$ & $\underline{\text { Lyc }}$ & $\underline{\text { Lyc }}$ & & 0.28 & 0.21 & 0.20 & 0.26 & 0.24 & 0.25 & 0.24 & 0.25 \\
\hline 10 & Nom & $\overline{\mathrm{Lyc}}$ & $\overline{\mathrm{LyC}}$ & Omm & & 0.35 & 0.32 & 0.38 & 0.32 & 0.27 & 0.27 & 0.26 \\
\hline 11 & Omm & Lyc & Lyc & Lyc & Lyc & & 0.31 & 0.55 & 0.30 & 0.49 & 0.40 & 0.48 \\
\hline 12 & $\overline{\mathrm{Omm}}$ & $\underline{\text { Lyc }}$ & $\overline{\mathrm{Lyc}}$ & Omm & $\underline{\mathrm{Lyc}}$ & $\underline{B r a}$ & & 0.53 & 0.41 & 0.50 & 0.33 & 0.55 \\
\hline 13 & $\overline{\mathrm{Omm}}$ & $\overline{\mathrm{Lyc}}$ & $\overline{\mathrm{LyC}}$ & Lyc & $\underline{\mathrm{Omm}}$ & $\underline{\overline{\mathrm{Omm}}}$ & $\underline{\mathrm{Omm}}$ & & 0.44 & 0.57 & 0.56 & 0.55 \\
\hline 14 & $\overline{\mathrm{Omm}}$ & $\overline{\mathrm{Lyc}}$ & $\overline{\mathrm{LyC}}$ & Lyc & $\underline{\mathrm{Lyc}}$ & $\overline{\mathrm{Omm}}$ & $\overline{\mathrm{Omm}}$ & $\underline{\mathrm{Omm}}$ & & 0.53 & 0.44 & 0.53 \\
\hline 15 & Lyc & Lyc & Lyc & Omm & Lyc & $\overline{\mathrm{Omm}}$ & $\overline{\mathrm{Omm}}$ & $\overline{\mathrm{Omm}}$ & $\underline{\mathrm{Omm}}$ & & 0.20 & 0.36 \\
\hline 17 & $\underline{\text { Lyc }}$ & Lyc & $\underline{\text { Lyc }}$ & Omm & Lyc & $\underline{\mathrm{Omm}}$ & $\underline{\mathrm{Omm}}$ & $\underline{\mathrm{Omm}}$ & $\underline{\mathrm{Omm}}$ & Tel & & 0.31 \\
\hline 18 & Lyc & Lyc & $\underline{\text { Lyc }}$ & Omm & Lyc & $\underline{\mathrm{Omm}}$ & $\underline{\mathrm{Omm}}$ & $\underline{\mathrm{Omm}}$ & $\underline{\mathrm{Omm}}$ & Tel & $\underline{\mathrm{Omm}}$ & \\
\hline
\end{tabular}




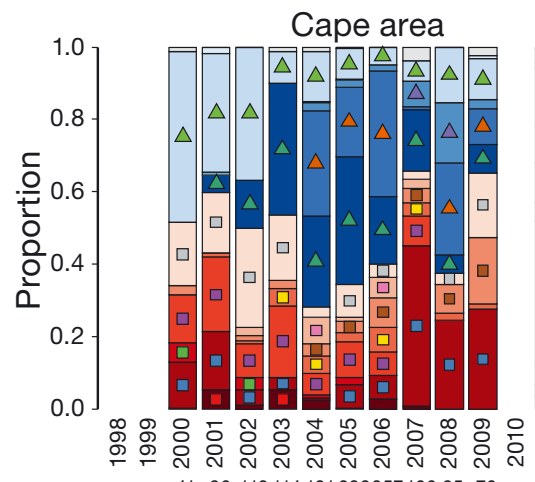

41861191141812303571668576

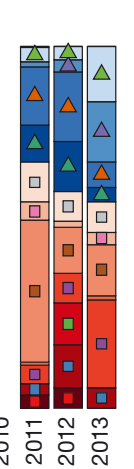

926195
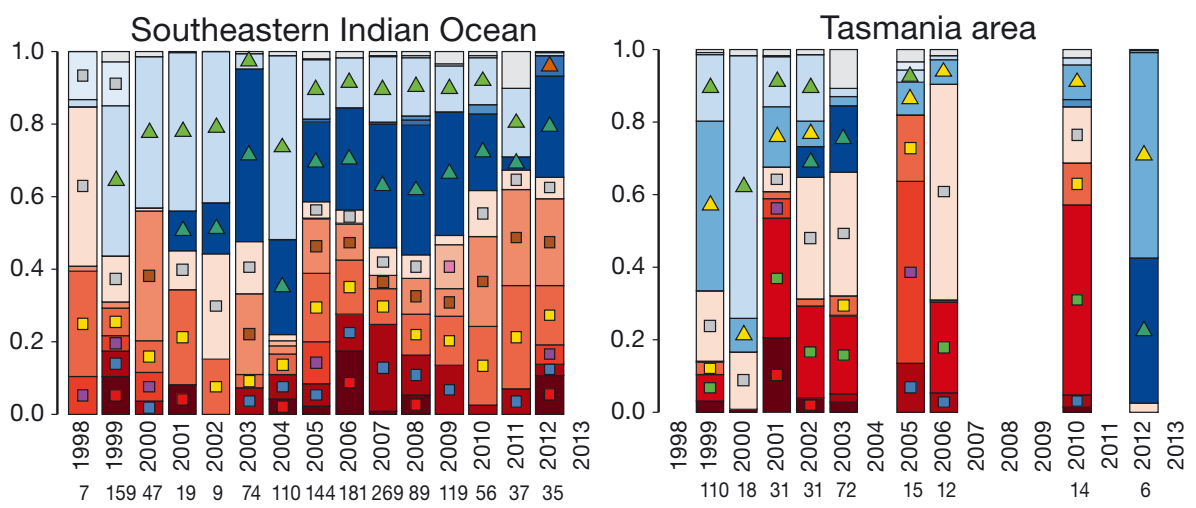

Fig. 8. Weight composition of the stomach contents of southern bluefin tuna by year for the 3 study areas. See legend in Fig. 3 for explanation of symbols. Numbers below the year represent the sample size. Compositions in years with $<5$ tuna are not shown

Prey weight compositions by month, latitude, and longitude are available in Figs. S4 to S6 in the Supplement. Prey composition by month changed seasonally in the southeastern Indian Ocean, and in all months examined, the stomachs of smaller SBT contained a larger proportion of cephalopods (data not shown). This phenomenon was considered to be secondary and a reflection of the fact that smaller SBT were more common in July and August samples. The patterns of prey composition as functions of latitude and SST were similar. However, there were monthto-month inconsistencies in the latitudes from which the samples were obtained. For example, the most southern latitude that was sampled shifted from $44^{\circ} \mathrm{S}$ in July to $41^{\circ} \mathrm{S}$ in October in the southeastern Indian Ocean. In contrast, the SST of all samples was consistently in the range of 10 to $12^{\circ} \mathrm{C}$ in all months from August to December and $10^{\circ} \mathrm{C}$ in July. Differences in prey composition as a function of longitude have already been considered in the discussion of the differences and similarities between areas, which were classified on the basis of longitude. The nMDS figures for month, latitude, and longitude and results of the SIMPER analyses for year, SBT size, and SST in the 3 areas are available in the Supplement in Figs. S7 to S9 and Tables S3 to S5, respectively.

\section{Body size of ommastrephids}

Even if prey composition did not change as a function of any variable, the sizes of prey may have differed. Although a detailed evaluation was not possible because of the difficulty of quantifying weight loss from digestion, distinct effects of variables on the size of ommastrephids were apparent. The median body weights of ommastrephids, with the exception of digestion stage $\mathrm{D}$, were significantly smaller in the southeastern Indian Ocean $(17 \mathrm{~g})$ than in the Cape area $(206 \mathrm{~g})\left(F\right.$-test for $\log \left(\right.$ body weight); $F_{(1,1793)}=$ 1257, $\mathrm{p}<0.01$; Fig. 9). In the southeastern Indian Ocean, monthly median weight increased from $10.4 \mathrm{~g}$ in August to $87.0 \mathrm{~g}$ in December. Although weight loss during digestion was not considered in this result, increases in the body weights of ommastrephids with month were observed even if the data were limited to each of the digestion stages A, B, or C. As described above, ommastrephids accounted for a large part of the prey of smaller SBT in the southeastern Indian Ocean, and the ommastrephids found in smaller SBT $(<100 \mathrm{~cm}$ FL) in this area were generally small, with weights ranging from 2.2 to $37.0 \mathrm{~g}$ and averaging $7.9 \mathrm{~g}(\mathrm{n}=253)$.

\section{DISCUSSION}

\section{Food webs in the southern temperate oceans of the southern hemisphere}

Top predators such as SBT can play the role of biological samplers of the mid-trophic animals that they consume, and they can thereby reveal the distribution and ecology of their prey, which can be difficult to collect (Young et al. 2015). Sampling of the stomach contents of top predators by onboard scientific observers is therefore an effective approach in oceanic ecological studies (Nicol et al. 2013). The present study was based on the stomach contents of SBT collected by such observers; the results provide previously unavailable details of the food-web linkages in southern temperate oceans of the southern hemisphere. Previously, details of the foraging ecology of top predators in this area were only available for SBT 

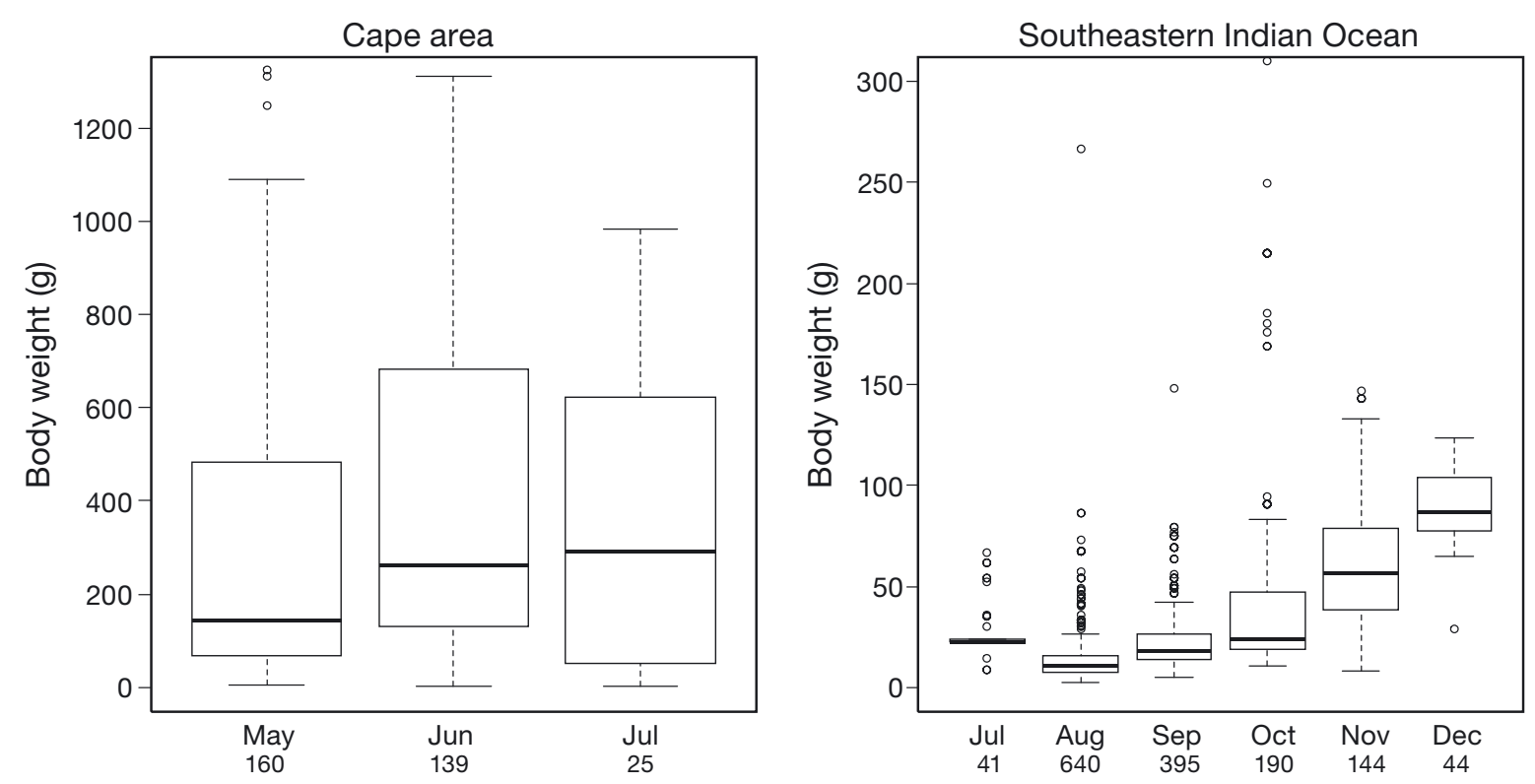

Fig. 9. Monthly body weight of ommastrephids found in the stomachs of southern bluefin tuna for 2 study areas. Values are for all years combined. Values represent the median (horizontal line), the 25th and 75th percentiles (box), and 1.5 times the interquartile range (range bars); individual data points represent outliers. The numbers below the $x$-axis labels are the number of ommastrephids

in the Tasmania area (Young et al. 1997). The new data will be useful for supporting the development of ecological models.

Previous observations have shown that the prey of SBT are more diverse in the open ocean than in the coastal waters around Tasmania (Young et al. 1997). The present study also recorded a wide variety of prey items, with 62 groups of prey identified to the family level; thereby providing details of predatorprey interactions for SBT in a wider part of the southern hemisphere than in the previous study.

As SBT grow, their mouths becomes larger and they can swim faster, which allows them to feed on larger animals. Larger SBT can also dive deeper and tolerate lower temperatures, which provides access to prey in deep water (Patterson et al. 2008). However, prey composition does not appear to change as SBT grow larger ( $>120 \mathrm{~cm} \mathrm{FL}$; Young et al. 1997; our Fig. 4). This lack of diet change even as SBT grow suggests that there might be no other animals (species that are larger, swim faster, or live in deep water) that attract predation by SBT in the southern oceanic ecosystem. To evaluate this possibility, we need data not only for prey found in SBT stomachs, but also for the distribution and biomass of other potential prey animals.

Unfortunately, the major prey items that we identified are not target species for commercial fisheries, so little information has been obtained. Relying on data from top predators as biological samplers is imperfect, but it is the best alternative currently available. The features of the southern oceanic food web inferred thus far are from the perspective of just 1 predator (SBT). In a study of the eastern waters of Australia that compared prey compositions among various top predators, prey compositions differed both in terms of the vertical habitat and the feeding time of the predators (Young et al. 2010). Because prey composition may also differ among predators in our study areas, stomach contents analyses of different top predators in future research would provide additional important details of potential food-web linkages.

No long-term trends in prey composition were observed in the stomach contents collected during the $15 \mathrm{yr}$ of our study, although some anomalies were found in several years. These anomalies between or within years and areas were attributed mainly to changes in cephalopod prey. Cephalopods have short lives and generation times, and their populations respond rapidly to annual environmental variability (Rodhouse 2013), resulting in large fluctuations in their abundance and related changes in the food web.

Concerning lycoteuthids, Young et al. (1997) reported the occurrence of Lycoteuthis lorigera in the Tasmania area. Okutani (2005) reported that lycoteuthids were also found near New Zealand. The absence of lycoteuthids in the Tasmania area in the present study might be explained by the low number 
of samples collected after 2004, when lycoteuthids were first identified in our study area. However, the absence of lycoteuthids in the southeastern Indian Ocean in the present study appears to be a definitive result because it is based on a large number of SBT samples.

\section{Foraging ecology of SBT in the open ocean}

Based on previous studies, SBT of up to $4 \mathrm{yr}$ old (mean FL at age for SBT are $52 \mathrm{~cm}$ at age $1,78 \mathrm{~cm}$ at age $2,96 \mathrm{~cm}$ at age 3 , and $113 \mathrm{~cm}$ at age 4 ; Gunn et al. 2008) foraging on the Australian continental shelf feed exclusively on teleosts (Serventy 1956, Young et al. 1997, Ward et al. 2006, Itoh et al. 2011). In contrast, the results of the present study are quite different, with $51 \%$ of the prey weight in the open ocean accounted for by cephalopods and $46 \%$ by teleosts. This agrees with the prey composition by weight of SBT in the open ocean previously reported for the Tasmania area: $54 \%$ cephalopods and $43 \%$ teleosts (Young et al. 1997). The results of the present study for most years show that SBT prey in the open ocean comprised almost equal weights of cephalopods and teleosts, not only in the Tasmania area, but also in the other areas. Teleosts have usually dominated in previous reports of the stomach contents of top predator fishes in open-ocean areas. This was true for yellowfin tuna Thunnus albacares, striped marlin Tetrapturus audax, blue marlin Makaira nigricans, blue shark Prionace glauca, opah Lampris guttatus, dolphin fish Coryphaena hippurus, and lancet fish Alepisaurus spp. (Shimose et al. 2006, Young et al. 2010, Choy et al. 2013, Olson et al. 2014). In a few species, such as albacore tuna Thunnus alalunga, bigeye tuna Thunnus obesus, and swordfish Xiphias gladius, cephalopods compose more than $50 \%$ of the prey by weight (Watanabe et al. 2009, Young et al. 2010, Logan et al. 2013), as was the case for SBT in the present study.

Young et al. (1997) reported the occurrence of many jack mackerel Trachurus declivis in SBT stomachs in the open ocean of the Tasmania area. Because $T$. declivis is distributed from the continental shelf to the edge of the shelf, they hypothesized that SBT moved to the open ocean after consuming $T$. declivis at the shelf edge. Unusual prey items from around the shelf edge were also reported by Talbot \& Penrith (1963), who found that SBT fed on cape hake Merluccius capensis and prawns Funchalia woodwardi at the shelf edge west of South Africa. These studies used samples collected within approximately
$200 \mathrm{~km}$ from the shelf edge, where fish populations would be influenced by conditions at the shelf edge. In the present study, we collected samples far outside of the shelf zone to more directly reflect open-ocean foraging habits.

SBT distribution shifts as individuals age: from age 0 to 1, SBT are found on the continental shelf, from age 2 to 4 they migrate seasonally between coastal and open-ocean habitats, and after age 5, they are found primarily in the open ocean (Caton 1991, Farley et al. 2007). These shifts in the distribution of SBT lead to changes in the composition of their prey. Analogous shifts in the foraging habits of tunas occur between their larval and juvenile stages (Uotani et al. 1990, Young \& Davis 1990, Tanabe 2001): up to age 1, the prey composition changes in response to increasing tuna size and diving ability (Sinopoli et al. 2004, Graham et al. 2007, Shimose et al. 2013). The shift in prey composition as SBT move from the continental shelf to the open ocean represents a third example of a shift in foraging habits related to ontogenetic development.

SBT are believed to be opportunistic feeders (Serventy 1956, Shingu 1978). In the present study, we found no exclusively dominant prey taxa: the prey composition was diverse, and differed among areas. Assuming prey community composition varied spatially, the observed variation in SBT diet across regions suggests that SBT fed on whatever animals were available at the time and in the area where they were present, which supports the hypothesis that SBT are opportunistic feeders. The prey size also ranged widely, from as small as $0.2 \mathrm{~g}$ (amphipods) to as large as $3395 \mathrm{~g}$ (bramids).

The size of the ommastrephids found in SBT stomachs differed among areas and months. Ommastrephids in the southeastern Indian Ocean were substantially smaller than those in the Cape area, and increased in size from August to December. Although we could not identify the ommastrephids to lower than family level, this body weight increase was slower than the growth of 2 representative ommastrephid species in the southeastern Indian Ocean: Nototodarus gouldi and N. sloanii (Uozumi et al. 1995). Because spawning of these squids takes place throughout the year (Uozumi 1998), SBT seem to feed on small ommastrephids that grow there and also on new recruits from various spawning dates in the southeastern Indian Ocean.

SBT at ages 2 and 3 are found north of $35^{\circ} \mathrm{S}$ in the central Indian Ocean in winter (Farley et al. 2007, Bestley et al. 2009). However, the fact that SBT at ages 2 and 3 are caught by the Japanese longline 
fishery in the area south of $35^{\circ} \mathrm{S}$ in July and August suggests that some of these individuals move south in the southern hemisphere winter. For such small SBT that have just arrived in a new area, small ommastrephids would be an appropriate prey animal suitable for their mouth sizes and their lesser mobility horizontally and vertically compared with adults. A reliable supply of prey in the new area may facilitate habitat expansion by SBT towards colder southern waters.

\section{Constraints of the present study and future research}

The present study was based on a large number of samples collected over a long period of time and a wide geographical range. Although there was a large temporal bias in the monthly samples collected in each area, this bias arose from seasonal differences in SBT distribution as a result of their seasonal feeding and spawning migrations (Shingu 1978). The fishing seasons of the Japanese longline fishery, records of which date from the 1960s, appear to reflect the distribution of SBT. We therefore hypothesized that we could collect samples from the months when SBT were present in each of the 3 areas.

There are several other areas where SBT are known to be present in substantial densities. One of the major Japanese longline fishing grounds for SBT is around New Zealand. Most Japanese longline fleets left the Tasmania area in the mid-2000s because of the very low catch rates, but they have returned in recent years. The central Indian Ocean north of $35^{\circ} \mathrm{S}$ is the fishing ground for Taiwanese longline fleets targeting young SBT, and the spawning area south of Java, Indonesia, is the fishing ground for the Indonesian longline fleets (Farley et al. 2007). Further diet research in these areas is warranted, and SBT sampling should be feasible because of the presence of these fishing fleets.

There are several potential biases that result from sampling via the longline fishing method. In this method, an unknown time (typically more than several hours) passes between feeding on wild prey and feeding on bait (i.e. hooking of the SBT) and between hooking and sampling of the stomach (immediately after the fish is pulled onto the vessel); this means that the stomach contents may undergo digestion for an unknown but probably long time. In the present analyses, digestion was accounted for by the stage of digestion, which assumes that digestion rates are equal for all prey types. In an experiment on gastric evacuation of captive yellowfin tuna (Olson \& Boggs 1986), digestion speed differed according to the lipid composition of prey species. Digestion may also vary with prey size, and identification may be influenced by digestion (e.g. Alepisaurus can be identified from its lower jaw bone even in a severely digested condition). Further research, including gastric evacuation rates of wild SBT, is warranted for precise and quantitative analysis of foraging ecology.

Weight was measured with a resolution of $10 \%$ in the worst case (i.e. $0.1 \mathrm{~g}$ per $1 \mathrm{~g}$ and $1 \mathrm{~g}$ per $10 \mathrm{~g}$ ). Some unknown portion of the water trapped within prey items was difficult to remove even after blotting prey on filter paper (Hyslop 1980). In addition, part of the prey weight was lost during digestion. Because it was quite difficult to quantify these factors, very precise weighing was not appropriate.

We used \%W as an index of prey importance in terms of energy gain. Several limitations have been pointed out for \%W: because it is based on pooled data for individuals, no confidence intervals can be determined, and \%W values can be greatly affected by an anomalously large prey item from a small number of stomachs (Chipps \& Garvey 2007). \%MW was proposed to overcome these limitations (Graham et al. 2007). However, the robustness of \%MW with respect to those limitations has yet to be fully evaluated. In our dataset, the most common number of prey items per stomach was 1 ; in such cases, there is a large difference between \%W and \%MW. We suggest here an alternative way of using bootstrapping to resample datasets for \%W. This provides confidence intervals and allows evaluation of the effect on $\% \mathrm{~W}$ of anomalously large prey items from a few stomachs. In stomach content analyses, selecting an appropriate diet measure is strongly dependent on the research question (Chipps \& Garvey 2007), and the merits and limitations of various measures should be reviewed and summarized.

Another potential bias relates to sampling depth. In a longline operation that targets SBT, baited hooks are usually set at depths ranging from 50 to $200 \mathrm{~m}$ (Okazaki et al. 1997, T. Itoh unpubl. data). This may explain why mesopelagic species such as Alepisaurus and paralepidids were frequently found in the present study. Electronic tag data have provided evidence that SBT at age 3 feed in the mesopelagic layer, based on changes in the specific visceral temperature after feeding events (Bestley et al. 2008, 2009). Older and larger SBT appear to be better adapted to colder water in deep layers, so feeding in the mesopelagic layer is expected (Patterson et al. 2008). However, it is possible that some SBT did not 
dive into the mesopelagic layer if prey were abundant in the surface layer. If this is the case, then these SBT would not have been captured by the longline operation, and their stomachs would not have been sampled in the present study. The stomach contents of yellowfin tuna captured by purse seines, a nearsurface fishing technique, had lower diversity than the stomach contents of fish caught by the longline method (Potier et al. 2007). Unfortunately, purse seine operations are not used for SBT in the open ocean, so we cannot compare the stomach contents between these 2 fishing techniques. Although the existence of a sampling bias was not confirmed, the possibility of such a bias should be considered when interpreting our results. Finally, there are potential biases that arise from analyses of stomach contents, as has been noted in the literature (Chase 2002). These include regurgitation of stomach contents between the time of hooking and landing of the fish on the vessel, the time of day that feeding events take place, and the fact that stomach contents provide only the composition of the most recently ingested food. Analysis of stable isotopes, which provides cumulative information on prey composition over weeks or months, would help to mitigate these biases (Sarà \& Sarà 2007, Logan et al. 2011, Varela et al. 2013).

\section{CONCLUSION}

Our data identified the important prey taxa of SBT in their open-ocean habitat. The proportions of cephalopods and teleosts differed from those of both juveniles in their coastal habitats and other top predators in the open oceans. Sampling of the stomach contents of top predators by onboard scientific observers is an effective approach in oceanic ecological studies. To improve our understanding of SBT foraging ecology, further research is needed on topics including stomach content analyses of other top predators in the same habitats, other approaches such as using stable isotopes, and quantifying other relevant factors such as rates of digestion and gastric evacuation. Insights from improved understanding of SBT foraging ecology may also deepen our understanding of temperate water ecosystems in the southern hemisphere and facilitate ecosystem modelling.

Acknowledgements. We are grateful to the researchers and workers who participated in the scientific observers program, or who served as observers, to the crew on the longline vessels, and to the Fisheries Agency of Japan. We thank the staff of the National Research Institute of Far Seas Fisheries who helped analyze the stomach contents. We appreciate 3 anonymous reviewers whose comments improved the manuscript.

\section{LITERATURE CITED}

Bertrand A, Bard FX, Josse E (2002) Tuna food habits related to the micronekton distribution in French Polynesia. Mar Biol 140:1023-1037

Bestley S, Patterson T, Hindell M, Gunn J (2008) Feeding ecology of wild migratory tunas revealed by archival tag records of visceral warming. J Anim Ecol 77:1223-1233

> Bestley S, Gunn J, Hindell M (2009) Plasticity in vertical behaviour of migrating juvenile southern bluefin tuna (Thunnus maccoyii) in relation to oceanography of the south Indian Ocean. Fish Oceanogr 18:237-254

Bizzarro J, Robinson H, Rinewalt C, Ebert D (2007) Comparative feeding ecology of four sympatric skate species off central California, USA. Environ Biol Fishes 80:197-220

Butler C, Rudershausen P, Buckel J (2010) Feeding ecology of Atlantic bluefin tuna (Thunnus thynnus) in North Carolina: diet, daily ration, and consumption of Atlantic menhaden (Brevoortia tyrannus). Fish Bull 108:56-69

Caton A (1991) Review of aspects of southern bluefin tuna biology, population and fisheries. In: Deriso RB, Bayliff $\mathrm{WH}$ (eds) World meeting on stock assessment of bluefin tuna: strengths and weaknesses. Inter-American Tropical Tuna Commission, La Jolla, CA, Special Report 7, p 181-357

CCSBT (Commission for the Conservation of Southern Bluefin Tuna) (2015) Report of the twenty second annual meeting of the Commission for the Conservation of Southern Bluefin Tuna, 12-15 October 2015, Yeosu, Republic of Korea

Chase B (2002) Differences in diet of Atlantic bluefin tuna (Thunnus thynnus) at five seasonal feeding grounds on the New England continental shelf. Fish Bull 100:168-180

Chipps SR, Garvey JE (2007) Quantitative assessment of food habits and feeding patterns. In: Guy CS, Brown ML (eds) Analysis and interpretation of freshwater fisheries data. American Fisheries Society, Bethesda, p 473-514

Choy CA, Portner E, Iwane M, Drazen JC (2013) Diets of five important predatory mesopelagic fishes of the central North Pacific. Mar Ecol Prog Ser 492:169-184

Clarke K, Warwick R (2001) Change in marine communities: an approach to statistical analysis and interpretation, 2nd edn.. PRIMER-E, Plymouth

> Cox SP, Essington TE, Kitchell JF, Martell SJD, Walters CJ, Boggs C, Kaplan I (2002) Reconstructing ecosystem dynamics in the central Pacific Ocean, 1952-1998. II. A preliminary assessment of the trophic impacts of fishing and effects on tuna dynamics. Can J Fish Aquat Sci 59: 1736-1747

> Farley J, Davis T, Gunn J, Clear N, Preece A (2007) Demographic patterns of southern bluefin tuna, Thunnus maccoyii, as inferred from direct age data. Fish Res 83: $151-161$

Ferry LA, Cailliet GM (1996) Sample size and data analysis: are we characterizing and comparing diet properly? In: MacKinlay D, Shearer K (eds) Proceedings of the symposium on feeding ecology and nutrition in fish. International Congress on the Biology of Fishes, July 14-18, 1996, San Francisco, CA, p 71-80 
Garcia S, Cochrane K (2005) Ecosystem approach to fisheries: a review of implementation guidelines. ICES J Mar Sci 62:311-318

Graham B, Grubbs D, Holland K, Popp B (2007) A rapid ontogenetic shift in the diet of juvenile yellowfin tuna from Hawaii. Mar Biol 150:647-658

Grewe PM, Elliott NG, Innes BH, Ward RD (1997) Genetic population structure of southern bluefin tuna (Thunnus maccoyii). Mar Biol 127:555-561

Griffiths S, Young J, Lansdell M, Campbell R and others (2010) Ecological effects of longline fishing and climate change on the pelagic ecosystem off eastern Australia. Rev Fish Biol Fish 20:239-272

Gunn J, Block B (2001) Advances in acoustic, archival, and satellite tagging of tunas. In: Block B, Stevens E (eds) Fish physiology, Vol 19. Tuna: physiology, ecology and evolution. Academic Press, San Diego, CA, p 167-224

> Gunn J, Clear N, Carter T, Rees A, Stanley C, Farley J, Kalish J (2008) Age and growth in southern bluefin tuna, Thunnus maccoyii (Castelnau): direct estimation from otoliths, scales and vertebrae. Fish Res 92:207-220

- Hillary RM, Preece AL, Davies CR, Kurota H and others (2015) A scientific alternative to moratoria for rebuilding depleted international tuna stocks. Fish Fish 17:469-482

Hobday A, Evans K, Eveson P, Farley J, Hartog J, Basson M, Patterson T (2016) Distribution and migration-southern bluefin tuna. In: Kitagawa T, Kimura S (eds) Biology and ecology of bluefin tuna. CRC Press, Boca Raton, FL, p 189-210

Hyslop EJ (1980) Stomach contents analysis - a review of methods and their application. J Fish Biol 17:411-429

Itoh T, Kemps H, Totterdell J (2011) Diet of young southern bluefin tuna Thunnus maccoyii in the southwestern coastal waters of Australia in summer. Fish Sci 77: 337-344

IUCN (International Union for Conservation of Nature) (2011) IUCN Red List of Threatened Species (ver. 2011.2). www. iucnredlist.org (accessed September 2015)

- Logan J, Rodriguez-Marin E, Goni N, Barreiro S, Arrizabalaga H, Golet W, Lutcavage M (2011) Diet of young Atlantic bluefin tuna (Thunnus thynnus) in eastern and western Atlantic foraging grounds. Mar Biol 158:73-85

> Logan J, Toppin R, Smith S, Galuardi B, Porter J, Lutcavage M (2013) Contribution of cephalopod prey to the diet of large pelagic fish predators in the central North Atlantic Ocean. Deep-Sea Res II 95:74-82

Moteki M, Arai M, Tsuchiya K, Okamoto H (2001) Composition of piscine prey in the diet of large pelagic fish in the eastern tropical Pacific Ocean. Fish Sci 67:1063-1074

Nicol S, Allain V, Pilling G, Polovina J and others (2013) An ocean observation system for monitoring the affects of climate change on the ecology and sustainability of pelagic fisheries in the Pacific Ocean. Clim Change 119:131-145

Okazaki M, Mizuno K, Watanabe T, Yanagi S (1997) Improved model of micro bathythermograph system for tuna longline boats and its application to fisheries oceanography. Bull Natl Res Inst Far Seas Fish 34:25-41

Okutani T (2005) Cuttlefishes and squids of the world. Seizando, Tokyo

> Olson RJ, Boggs CH (1986) Apex predation by yellowfin tuna (Thunnus albacares): independent estimates from gastric evacuation and stomach contents, bioenergetics and cesium concentrations. Can J Fish Aquat Sci 43: 1760-1775

> Olson RJ, Duffy LM, Kuhnert PM, Galván-Magaña F,
Bocanegra-Castillo N, Alatorre-Ramírez V (2014) Decadal diet shift in yellowfin tuna Thunnus albacares suggests broad-scale food web changes in the eastern tropical Pacific Ocean. Mar Ecol Prog Ser 497:157-178

> Patterson T, Evans K, Carter T, Gunn J (2008) Movement and behaviour of large southern bluefin tuna (Thunnus maccoyii) in the Australian region determined using pop-up satellite archival tags. Fish Oceanogr 17:352-367

> Potier M, Marsac F, Cherel Y, Lucas V, Sabatie R, Maury O, Menard F (2007) Forage fauna in the diet of three large pelagic fishes (lancetfish, swordfish and yellowfin tuna) in the western equatorial Indian Ocean. Fish Res 83: 60-72

R Development Core Team (2014) R: A language and environment for statistical computing. R Foundation for Statistical Computing, Vienna. www.R-project.org/

> Rodhouse P (2013) Role of squid in the Southern Ocean pelagic ecosystem and the possible consequences of climate change. Deep-Sea Res II 95:129-138

Sarà G, Sarà R (2007) Feeding habits and trophic levels of bluefin tuna Thunnus thynnus of different size classes in the Mediterranean Sea. J Appl Ichthyology 23:122-127

Serventy D (1956) The southern bluefin tuna Thunnus thynnus maccoyii (Castelnau) in Australian waters. Aust J Mar Freshwater Res 7:1-43

Shimose T, Shono H, Yokawa K, Saito H, Tachihara K (2006) Food and feeding habits of blue marlin, Makaira nigricans, around Yonaguni Island, southwestern Japan. Bull Mar Sci 79:761-775

Shimose T, Watanabe H, Tanabe T, Kubodera T (2013) Ontogenetic diet shift of age-0 year Pacific bluefin tuna Thunnus orientalis. J Fish Biol 82:263-276

Shingu C (1978) Ecology and stock of southern bluefin tuna. Fisheries study 31. Japan Association of Fishery Resources Protection, Tokyo (in Japanese)

Sinopoli M, Pipitone C, Campagnuolo S, Campo D, Castriota L, Mostarda E, Andaloro F (2004) Diet of young-of-theyear bluefin tuna, Thnunnus thynnus (Linnaeus, 1758), in the southern Tyrrhenian (Mediterranean) Sea. J Appl Ichthyology 20:310-313

Talbot F, Penrith M (1963) Synopsis of the biological data on species of the genus Thunnus (sensu lato) (South Africa). FAO Fish Rep 2:608-646

Tanabe T (2001) Feeding habits of skipjack tuna Katsuwonus pelamis and other tuna Thunnus spp. juveniles in the tropical western Pacific. Fish Sci 67:563-570

Uotani I, Saito T, Hiranuma K, Nishikawa Y (1990) Feeding habit of bluefin tuna Thunnus thynnus larvae in the western north Pacific Ocean. Bull Jpn Soc Sci Fish 56:713-717

Uozumi Y (1998) Fishery biology of arrow squids, Nototodarus gouldi and N. sloanii, in New Zealand waters. Bull Natl Res Inst Far Seas Fish 35:1-111

Uozumi Y, Koshida S, Kotoda S (1995) Maturation of arrow squids Nototodarus gouldi and $N$. sloanii with age in New Zealand waters. Fish Sci 61:559-565

- Varela J, Rodriguez-Marin E, Medina A (2013) Estimating diets of pre-spawning Atlantic bluefin tuna from stomach content and stable isotope analyses. J Sea Res 76:187-192

> Ward T, McLeay L, Dimmlich W, Rogers P and others (2006) Pelagic ecology of a northern boundary current system: effects of upwelling on the production and distribution of sardine (Sardinops sagax), anchovy (Engraulis australis) and southern bluefin tuna (Thunnus maccoyii) in the Great Australian Bight. Fish Oceanogr 15:191-207

- Watanabe H, Kubodera T, Yokawa K (2009) Feeding ecol- 
ogy of the swordfish Xiphias gladius in the subtropical region and transition zone of the western North Pacific. Mar Ecol Prog Ser 396:111-122

Young JW, Davis TLO (1990) Feeding ecology of larvae of southern bluefin, albacore and skipjack tunas (Pisces: Scombridae) in the eastern Indian Ocean. Mar Ecol Prog Ser 61:17-29

Young J, Lamb T, Le D, Bradford R, Whitelaw W (1997) Feeding ecology and interannual variations in diet of southern bluefin tuna, Thunnus maccoyii, in relation to

Editorial responsibility: Konstantinos Stergiou, Thessaloniki, Greece coastal and oceanic waters off eastern Tasmania, Australia. Environ Biol Fishes 50:275-291

Young J, Lansdell M, Campbell R, Cooper S, Juanes F, Guest M (2010) Feeding ecology and niche segregation in oceanic top predators off eastern Australia. Mar Biol 157:2347-2368

> Young J, Olson R, Menard F, Kuhnert P and others (2015) Setting the stage for a global-scale trophic analysis of marine top predators: a multi-workshop review. Rev Fish Biol Fish 25:261-272

Submitted: November 20, 2015; Accepted: June 21, 2016

Proofs received from author(s): July 21, 2016 